\title{
DOES ENVY DESTROY SOCIAL FUNDAMENTALS? THE IMPACT OF RELATIVE INCOME POSITION ON SOCIAL CAPITAL
}

Justina A.V. Fischer and Benno Torgler*

The Suntory Centre

Suntory and Toyota International Centres for Economics and Related Disciplines

London School of Economics and Political Science Houghton Street

London WC2A 2AE

\footnotetext{
* Justina A. V. Fischer, STICERD-LSE etc...., e-mail: J.Fischer@1se.ac.uk; Benno Torgler, Yale Center for International and Area Studies, Leitner Program in International \& Comparative Political Economy, 34 Hillhouse Avenue, P.O. Box 208206, New Haven, CT 06520 (USA), e-mail: benno.torgler@yale.edu. He is also associated with CREMA - Center for Research in Economics, Management and the Arts, Switzerland. Both authors gratefully acknowledge financial support from the Swiss National Science Foundation (SNF). We wish to thank Julia Angelica for professional editing.
} 


\begin{abstract}
Research evidence on the impact of relative income position on individual attitudes and behaviour is sorely lacking. Therefore, this paper assesses such positional impact on social capital by applying 14 different measurements to International Social Survey Programme data from 25 countries. We find support for a positional concern effect or 'envy' whose magnitude in several cases is quite substantial. The results indicate that such an effect is non-linear. In addition, we find an indication that absolute income level is also relevant. Lastly, changing the reference group (regional versus national) produces no significant differences in the results.
\end{abstract}

JEL Classification: Z130, H260, I310, D000, D600

Keywords: Relative income position; envy; positional concerns; social capital; social norms; happiness 


\section{Development Economics Discussion Paper Series}

This series is published by the Economic Organisation and Public Policy Programme (EOPP) located within the Suntory and Toyota International Centres for Economics and Related Disciplines (STICERD) at the London School of Economics and Political Science. The programme was established in October 1998 as a successor to the Development Economics Research Programme. The work of the programme is mainly in the fields of development economics, public economics and political economy. It is directed by Tim Besley, Oriana Bandiera, Robin Burgess, Maitreesh Ghatak and Andrea Prat. Further details about the programme and its work can be viewed on our web site at http://sticerd.lse.ac.uk/research/eopp.

Our Discussion Paper series is available free of charge. To subscribe to DEDPS, please contact Leila Alberici on:

$\begin{array}{ll}\text { Telephone: } & \mathrm{UK}+2079556674 \\ \text { Fax: } & \mathrm{UK}+2079556951 \\ \text { Email: } & \text { 1.alberici@1se.ac.uk } \\ \text { Web site: } & \text { http://sticerd.lse.ac.uk/dedps }\end{array}$

Tim Besley

Oriana Bandiera

Robin Burgess

Maitreesh Ghatak

Andrea Prat

(C) The authors. All rights reserved. Short sections of text, not to exceed two paragraphs, may be quoted without explicit permission provided that full credit, including $\mathbb{C}$ notice, is given to the source. 
Envy ... is a subtle and powerful feeling, motivating everything from political movements to murders.

(Richard Zeckhauser, 1991, p. 9)

\section{Introduction}

The subject of envy and its social repercussions has long preoccupied human secular selfreflection and contemplation. ${ }^{1}$ In economics theory, Adam Smith (1759/1976), like his successors Karl Marx (1849) and Thorstein Veblen (1899), emphasized the importance of relative position and social concerns. Since then, these ideas have been stressed by modern economists such as Arthur Pigou (1920), John Maynard Keynes (1930), James Duesenberry (1949) and Harvey Leibenstein (1950). In contrast to the traditional standard utility theory position that individuals evaluate their welfare only in absolute terms, the theory of envy creation assumes that individual welfare depends on comparisons with others. Whereas Smith (1759/1976) proposed relative wants as central to human behaviour and Marx (1849) emphasized that humans measure their wants and pleasure in relation to society, Veblen's (1899) concepts of conspicuous leisure and consumption stress the importance of an individual's relative position in society. Subsequently, by developing a utility concept characterized by systematically interdependent utilities, Duesenberry (1949) incorporated relative preferences into consumer theory. Even Marshall (1961), often seen as the creator of modern demand theory, notes the relevance of human distinction, while Leibenstein (1950) stresses the non-fiction demand for consumption goods due to, for example, a bandwagon effect in which others' behaviour affects individual choices.

\footnotetext{
${ }^{1}$ In the ancient world, Aristotle (1924) treated envy in his Rhetoric. During the age of enlightenment, Immanuel Kant, in his 1785 Metaphysics of Morals, and Francis Bacon, in his 1625 Of Envy, discussed in detail the psychology of ingratitude and schadenfreude, provided well-developed definitions of envy and emphasized the importance of social comparisons. Other, modern classical philosophers such as Schopenhauer, Kierkegaard, or Nietzsche have also stressed the function of envy in human society.
} 
It is therefore surprising that many economists have largely neglected this topic. In particular, there is a dearth of empirical research into the impact of relative income position on individual attitudes and behaviour (see Senik, 2005). Moreover, of the studies on relative income position that do exist, most focus on its association with happiness rather than its impact on social capital. To remedy this research void, this paper uses 14 different measures covering four different dimensions to produce detailed evidence on the relation between income position and several aspects of social capital.

Besides its narrow focus, the empirical research on the impact of envy or positional concerns has also been hindered by lack of data or inadequate methodology. As Ferrer-iCarbonell (2005) points out, "[m]ost economists have used (and are fond of) cross-section micro-empirical data, i.e., data at the individual level and for only one country" (p. 998). However, not only do relatively new international survey data sources now allow detailed investigation of social capital for a variety of countries, but more sophisticated statistical techniques and designs are also enabling researchers to take advantage of cross-national variations in these data.

Our study overcomes methodological shortcomings by using survey data from the 1998 wave (RELIGION II) of the International Social Survey Programme (ISSP), which not only covers approximately 24,000 persons in 25 countries but, in contrast to other ISSP waves, asks many questions related to various aspects of social capital. Moreover, in line with some previous studies, we include an almost complete set of control variables to better isolate partial correlations between relative income position and social capital.

The remainder of the paper is organized as follows. Section 2 develops the theoretical approach and predictions. Section 3 describes the dataset, and Section 4 presents the empirical results. Section 5 concludes the paper. 


\section{The Effect of Relative Income Position on Social Capital}

\subsection{The Role of Relative Income Position and Envy in Society}

In social science theory, positional concerns have historically been thought to play a role in the interaction between people meaning that many economic and social phenomena might be explained by the interdependence of individuals' utilities. Since Kant's (1785/1964) early emphasis on the importance of social comparisons, social psychology, sociology and anthropology have also traditionally placed much emphasis on the relevance and fundamentality of relative preferences to human motivation (see, e.g., Festinger, 1954 for the theory of social comparison; Stouffer, 1949 for the theory of relative deprivation). In addition, several economists have elaborated on the concept of interdependent preferences, whose inclusion in economic theory allows social comparisons (e.g., Becker, 1974; Easterlin, 1974; Scitovsky, 1976; Schelling, 1978; Pollak, 1976; Boskin and Sheshinski, 1978; Frank, 1985; Akerlof and Yellen, 1990). According to Frank (1991), not only do individual decisions have important consequences for the individual concerned, but they also generate what he terms positional externalities. To illustrate, he shows how such welfare comparisons between individuals help explain the existence of such diverse elements as 24-hour supermarkets, excessive formalism in economics, cycles of fashion and public spiritedness, muddled bureaucratic language, excessive cosmetic surgery and pressures to consume growth hormones. He concludes that "...the more we learn about them, the more likely it seems that actions without external effects may be the real exceptions" (p. 44). McAdams (1992) points out that social scientists have challenged the concept of selfishness "primarily by exploring ways in which preferences are positively dependent on each other, as when empathy, altruism, or moral commitment cause one person to desire that others be able to satisfy their 
own desires. Much less has been said about the extent to which preferences are negatively interdependent, and the economic consequences of such preferences" (p. 3).

In theory, not all positional concerns translate automatically into envy. Rather, envy is generated by positional concerns only when the individual's current situation is below his or her own aspiration level. In philosophy, in which envy has been viewed "as one of the inescapable questions of existence" (Schoeck, 1966, p. 194), it is Kant (1785/1964) who perhaps provides the most well-developed definition:

Envy (livor) is a tendency to perceive with displeasure the good of others, although it in no way detracts from one's own, and which, when it leads to action (in order to diminish that good) is called qualified envy, but otherwise only ill-will (invidentia); it is however only an indirect, malevolent frame of mind, namely a disinclination to see our own good overshadowed by the good of others, because we take its measure not from its intrinsic worth, but by comparison with the good of others and then go on to symbolize that evaluation. (Cited in Schoeck 1966, p. 201)

Ainslie (1992) argues that “[p]utting oneself in another's shoes may offer a single, distinct, and thus robust alternative to the perception of life in one's own shoes. This alternative perception of reality is experienced as envy" (p. 323). Not only do social scientists - including social psychologists, anthropologists, sociologists and political scientists - stress the important role of envy in everyday life (e.g., Foster, 1967; Elster, 1991), but several economists, primarily in 1970s literature on welfare economics, also discuss the significance of envy (e.g., Foley, 1967; Brennan, 1973; Varian, 1974; Archibald and Donaldson, 1979). Subsequently, using a rational choice framework, Mui (1995) incorporates envy into standard economic theory to explore agents' sabotage or retaliative behaviour against others.

In real life, individuals' relative judgments of their own positions do appear commonplace (see Frank, 1985; Frank and Sunstein, 2001; Solnick and Hemenway, 1998; 
Zeckhauser, 1991; Tversky and Griffing, 1993; Johansson-Stenman et al., 2002 and Alpizar et $a l .$, 2005). That is, people tend to compare themselves with their environment and care greatly about their relative position, which in turn influences their attitudes and observable behaviour. Moreover, as German social scientist Helmut Schoeck (1966) amply demonstrates, envy is a widespread social phenomenon that engenders myriad everyday actions aimed at reducing it. For example, school uniforms are thought to reduce possible envy among pupils and schoolteachers may ask parents not to incite envy in classmates by packing special treats in their children's lunchboxes (Elster, 1991). An extreme example of envy reduction occurred in China during the Cultural Revolution when farmers owning fruit trees were ordered to cut them down (Zhang and Sang, 1987, cited in Elster, 1991).

Indeed, systematic tests carried out by psychologists and economic psychologists suggest that people do take into account relative income position when making real life decisions such as choosing between two earning schemes. Economic psychologists Frank and Sunstein (2001) hypothesize two possible worlds: in world A, the individual earns $\$ 110,000$ a year, while colleagues earn $\$ 200,000$; in alternative world B, the individual earns less than in world A $(\$ 100,000$ per year), but the others earn only $\$ 85,000$ (p. 336). In a traditional economic approach, world A should be preferable because it offers higher absolute consumption. However, the choices made by test subjects paint a different picture - that is, a substantial number of respondents opted for world B, thereby confirming Frank's (1985) earlier findings using similar tests. Solnick and Hemenway (1998), who test 257 faculty, students and staff members at Harvard School of Public Health using a similar scenario, find that approximately 50 percent of their respondents preferred the world in which they had a higher relative income position. Likewise, Johansson-Stenman et al. (2002) and Alpizar et al. (2005) find evidence that absolute and relative income, as well as consumption, matter for individual utility or well-being. Finally, Tversky and Griffin (1993), in a study of the relation between envy and happiness, observe that 85 percent of their test subjects chose the world 
with the higher absolute salary and the lower relative position. However, interestingly, 62 percent anticipated a higher job satisfaction in the world with the higher relative income position. Similar results are also reported for comparisons at the macro level (e.g., Zeckhauser, 1991).

Experimental economists have also discovered the relevance of incorporating envy into such research tasks as explaining outcomes in ultimatum games in which two or more persons must agree on how to share a given amount of money (see, e.g., Kirchsteiger, 1994). Frank and Sunstein (2001) stress that “... preference for good relative position does not explain all of what occurs in the game; ensuring a fair outcome, which may or may not call for good relative position, is often the driving factor. But relative position also counts for many participants, so much so that 'difference aversion' appears to motivate a significant percentage of participants" (p. 344). A decade earlier, Elster (1991) had even gone so far as to criticize the sense of fairness that characterizes experimental evidence from ultimatum games, suggesting that a sense of envy "would sometimes be more appropriate for analogous behavior in real life" (p. 66). Thus, the welfare of an envious person increases the danger that others' assets will be destroyed, even when such destruction has its own costs.

\subsection{Dependent Variables: Social Capital}

Economists have discovered social capital - widely studied and highly prominent in all social sciences - to be an important determinant of economic phenomena like macroeconomic performance. For example, Knack and Keefer (1997), in a cross-sectional analysis, find a strong and significantly positive relationship between social capital variables (civic duty) and economic growth. Schaltegger and Torgler (2005), using data for a synthetic panel of Swiss cantons over the 1981-2001 period, show that trust enhances fiscal performance. As regards public finance, Slemrod (1998) argues that social capital - measured as the willingness to pay 
taxes voluntarily - lowers the cost of government operations and of equitably assigning such cost to citizens. Such research justifies a closer look at what shapes social capital.

The notion of social capital encompasses multiple aspects; however, the traditional social capital variable 'trust' is viewed as having two facets: trust among people and the people's trust in national institutions (see, e.g., Glaeser et al., 2000; Knack, 2000; Uslaner, 2002). Therefore, the following discussion focuses on four dimensions: trust between people and trust of the people in institutions, social norms and/or networks (Putnam, 2001; Bjørnskov, 2005).

Because generalized trust, the belief that most people can be trusted, does not depend on a specific individual or on group characteristics (see, e.g., Uslaner, 2002), we measure it using the following question: "Generally speaking, would you say that people can be trusted or that you cannot be too careful in dealing with people?". Generalized trust is also expressed by the perception of others' fairness towards oneself (e.g., "How often do you think that people would try to take advantage of you if they got the chance and how often would they try to be fair?").

Whereas generalized trust is shaped by the horizontal relation between citizens, trust in state institutions is a key factor in measuring the vertical interaction between citizens and the state. Thus, in a further step, we also include four questions - such as "How much confidence do you have in institution X?" - to test several facets of particularized or institutional trust. The important institutions to be analyzed are parliament, the courts and legal system, businesses and industries, and social institutions like the church and religious organizations.

The second dimension of social capital, compliance with social norms, is measured using questions related to tax morale, government benefit morale and compliance with legal norms. Because traditional economic models of tax evasion predict far too little compliance and far too much infringement, tax compliance seemingly depends on numerous factors that 
go beyond standard economic concepts like deterrence. To resolve this conundrum, many researchers suggest that the intrinsic motivation for individuals to pay taxes - what in the literature is termed 'tax morale' - helps explain these high levels of tax compliance (see, e.g., Lewis, 1982; Roth et al., 1989; Alm et al., 1992, 1999; Pommerehne et al., 1994; Frey, 1997, 2003; Frey and Feld, 2002; Torgler, 2002, 2003, 2005a, 2006a,b). Thus, in line with previous research (see Torgler, 2005b,c), we assess the level of tax morale using the following question: "Do you feel it is wrong or not wrong if a taxpayer does not report all of his or her income in order to pay less income taxes?". The benefit morale (see Halla and Schneider, 2005 ) - that is, the acceptance of claiming government benefits without being entitled to them - we investigate in a similar manner. Compliance with legal norms like criminal and traffic laws is measured by the following moral dilemma: "Suppose you were riding in a car driven by a close friend. You know he is going too fast. He hits a pedestrian. He asks you to tell the police that he was obeying the speed limit." Thus, our social norm variables are proxies for three different ethical questions in daily life.

The networking aspect of social capital we measure by the level of civic engagement in voluntary work, such as charitable activities, religious and church-related activities, political activities and so forth. This set of social capital variables alone relates not to attitudes but to actual self-reported behaviour. Moreover, such activities generate more intense interactions between people, particularly between group members (Putnam, 2000). This networking aspect is measured by the following question: "How often in the last 12 months did you do volunteer in any of the following areas...?" Obviously, building up a social network through such interactions between people is linked to the degree of trust within a community. In addition, it seems probable that networks might generate positive externalities and thus more trust among and in those people who are not formally part of such organizations; for example, strangers in the community (Putnam, 2000). Nevertheless, 
evidence for such externalities is not detectable in the empirical literature (for an overview, see Bjørnskov, 2005).

Finally, we investigate happiness, a variable that cannot be interpreted as a social capital variable but that nevertheless has a strong connection with it. Specifically, social networks may have a strong positive impact on happiness (see, e.g., Baker, 2005) and so might generate trust among people and in institutions. Moreover, in contrast to the other variables, happiness, as alluded to earlier and shown in the next section, is a key variable in the research stream on the impact of relative income position. As such, happiness serves as a type of benchmark variable.

\subsection{Hypotheses: 'Keeping Up with the Joneses'}

This paper aims to test the importance of an individual's relative income position, or envy, on the subjective social capital level. In general, the study assumes that individuals' social capital and subjective well-being depends on the distance between their own and the reference group's income. We formulate our formal hypotheses based on pioneer work in the happiness literature on the impact of relative income position. Not only do Clark and Oswald (1996) suggest that the dependence of happiness on relative income is "one of the most interesting ideas in social science" (p. 359), but Frank and Sunstein (2001) point to "happiness surveys conducted over time in a variety of countries" as "[p]erhaps the most striking evidence of the importance of relative position" (p. 337). Indeed, much happiness research finds strong evidence for the positive impact of the relative position on subjective well-being (Easterlin, 1974, 1995, 2001; Clark and Oswald, 1996; Watson et al., 1996; Groot and van den Brink, 1999; Tsou and Liu, 2001; McBride, 2001; Lyubomirsky, 2001; Stutzer, 2004; Kingdon and Knight, 2004; Dorn et al., 2005; Luttmer, 2005; Ferrer-i-Carbonell, 2005). Based on these happiness studies, we first predict the following: 
Hypothesis 1: Not being able to 'keep up with the Joneses' reduces an individual's level of self-reported happiness.

In addition, individuals' positional concerns or the degree of envy may equally affect the generalized trust level; that is, the mutual trust among people. Most particularly, positional concerns are linked with frustration ("it could have or should have been me") and the unhappiness and resignation of not being able to 'keep up with the Joneses'. Such feelings may lead not only to distrust of the Joneses (i.e., the reference group) but also of other citizens, which reduces the generalized trust and the perceived fairness level. Based on these thoughts, we develop our second hypothesis.

Hypothesis 2: Positional concerns (disadvantage in the relative income position) decrease people's trust in others and their perceptions of others' fairness.

In addition, individuals may blame the state or its institutions for the relative income disadvantage they experience compared to the Joneses. Thus, frustration or resignation may lead not only to a decrease in trust at the horizontal level (generalized trust) but also at the vertical level; that is, the relation between the government and the citizen. The degree to which these social institutions are held responsible by individuals for their current social position may depend on the perceived degree to which the institution influences societal outcomes. For example, parliament is linked to the current politico-economic level; the courts and the legal system, to the constitutional level. Because of stronger long-term effects (blaming the 'rules of the game'), we may expect a stronger impact of positional concerns on institutions at the constitutional level. On the other hand, short-term and unexpected policy changes are more prominent among the law-making bodies, where decision-making is faster 
and new governments occur more often. The influence of these institutions at the current politico-economic level might be particularly strong when people have adjusted their aspiration levels to the long-term determinants of their social position. Moreover, because envy is a widespread phenomenon in the workplace (see, e.g., Layard, 2003; Elster, 1991; Frank and Sunstein, 2001), positional concerns may also affect many individuals' trust in the environment of business and industry in which they are involved daily. In other words, individuals may blame business or industry for their relative income disadvantage, which could lead to a decreased level of trust in that social sector. Thus, our third hypothesis suggests the following:

Hypothesis 3: A decrease in relative income position lowers trust in societal institutions such as the courts, parliament and business and industry.

In contrast, religious institutions provide moral constitutions for a society. On the one hand, religion acts as a type of 'supernatural police' that provides a certain level of enforced compliance with socially accepted rules (Anderson and Tollison, 1992). Equally, it encourages the production of social goods such as moral behaviour rooted in, for example, the Ten Commandments (Hull and Bold, 1994). On the other hand (and more specifically), envy may be controlled and restrained by religion. Fundamentally, all world religions teach the avoidance of envy. For example, according to Jewish tradition, causing others to feel ashamed and creating envy through one's own behaviour is unlawful. Similarly, in the Qur'an, Mohammed describes envy as a sickness and the "shearer of religion". Buddhism regards envy as one of the so-called five poisons that may lead to continuous re-birth and must therefore be overcome. In Hinduism, the avoidance of envy is a yama, an advised restraint (rather than a commandment) that should be followed. As regards Christianity, Schoeck (1966) points out the following: 
The ethic taught by the New Testament sought to secure differentiated human existence in a world full of envious people and unlikely to evolve into a society of equals ... Again and again we find parables the tenor of which is quite clearly the immorality, the sin of envy.... In the West, the historical achievement of this Christian ethic is to have encouraged and protected, if not to have been actually responsible for the extent of, the exercise of human creative powers through the control of envy. (pp. 159-160)

We can therefore expect that positional concerns may not affect people's trust in churches and religious organization because these provide mechanisms for catalyzing the feeling of envy. In addition, all religions have elaborated a sanctioning system that legitimizes and reinforces social values, providing support for toleration of inequality and legitimizing noticeable differences in individual circumstances in the interest of social peace. These observations lead to our fourth hypothesis:

Hypothesis 4: The level of trust in churches and religious organizations should not be affected by a disadvantage in relative income position.

Social comparisons may also have an impact on willingness to comply with social and legal norms; for example, relative income position may affect willingness to pay taxes (tax morale). Frey and Torgler (2004), using survey data for 30 European countries, show that if taxpayers believe tax evasion to be common, their tax morale decreases. If, however, they believe others to be honest, their tax morale increases. These findings indicate that taxpayers observe the pro-social behaviour of other taxpayers and pay their taxes conditionally. The extent to which others also contribute triggers greater or less cooperation and systematically influences an individual's own willingness to comply. Thus, we may also observe social 
comparison mechanisms related to the relative income position for compliance with social norms. A relative disadvantage may lead to a lower tax morale or benefit morale by creating dissatisfaction and a sense of distress over the discrepancy between the actual and the aspiredto financial situation.

In such a scenario, cheating the government by not paying taxes and claiming unjustified government benefits might serve as means for an 'illegal' income redistribution by the socially deprived. Indeed, there is evidence that such positional distress can cause a decrease in the level of tax morale (see Torgler, 2006a,b). Similarly, Torgler, Schmidt and Frey (2005) show empirically that the larger the income differences within a German soccer team, the worse the performance (i.e., effort to comply) of the single players. Yet, what of compliance with criminal and traffic law? If, as previous observations suggest, we can expect social capital to be positively affected by an advantage in relative income position, the same should be observed for a general compliance with law, even if the infringer is a close friend. Thus, our fifth hypothesis is as follows:

Hypothesis 5: A better relative income position leads to a stronger willingness to obey the law and comply with norms.

Lastly, voluntary participation in political organizations and activities might be caused by an incentive to express personal preferences or even change the social structure via political channels like redistribution policies. Similarly, an individual may become involved in institutions that correct or deal with relative social disadvantages through charitable (e.g. helping the sick, elderly or poor) or religious and church-related activities, even without benefiting directly from such action. Based on these thoughts, we develop our final hypothesis: 
Hypothesis 6: Positional concerns lead to more frequent active participation in voluntary activities, whether political, charitable or religious.

\section{Data}

This analysis uses a cross section of individual data from the 1998 ISSP survey, which contains various questions related to four dimensions of social capital - trust between people and people's trust in social institutions, norms and networks. In addition, we include the happiness question as a generic measure of social capital. The categorical dependent variables have been recoded so that higher values correspond to higher levels of social capital. Important to our analysis is the fact that this dataset not only covers approximately 22,000 observations from 25 countries but provides information on personal income, our variable of interest, and various additional socio-demographic variables usually employed in multivariate analyses of issues such as tax morale, health status or life satisfaction (see, e.g., Torgler, $2006 b$ and Dorn et al., 2005). To make income comparable across countries and persons, PPP-adjusted equivalent income in US dollars is calculated based on the World Penn Tables 6.1 (Heston et al., 2002) and the modified OECD equivalence scale (Van Doorslaer and Masseria, 2004). National average income is computed as the average of the personal equivalence income observed in one country, and analogously, as the regional average income for regions. If fewer than 30 observations exist for one region, larger entities are formed for statistical inference. The subsistence income is measured as 40 percent of the average income of a country or region. Descriptive statistics for these variables are reported in Tables A1 to $\mathrm{A} 3$ of the appendix. 


\section{Model and Methodology}

In this cross-sectional model, we regard the level of social capital $\left(\mathrm{Y}_{\mathrm{i}}\right)$ as a function of the relative or absolute income position of an individual $\left(\mathrm{Z}_{\mathrm{i}}\right)$ and a vector of additional control variables $\left(\mathrm{V}_{\mathrm{i}}\right)^{2}$ and error term $\left(\varepsilon_{\mathrm{i}}\right)^{3}$

$$
\mathrm{Y}_{\mathrm{i}}=\beta_{1} \mathrm{Z}_{\mathrm{i}}+\beta_{2} \mathrm{~V}_{\mathrm{i}}+\varepsilon_{\mathrm{I}}
$$

To ensure comparability of the estimation results, computation for the various regressands employs the identical set of control variables $\left(\mathrm{V}_{\mathrm{i}}\right)$. Our variable of interest, relative income position $\left(\mathrm{Z}_{\mathrm{i}}\right)$, is measured in four different ways: $\left(\begin{array}{lll}1 & \& & 2\end{array}\right)$ the difference between an individual's income and the national (subsistence) income (difference) and ( $3 \& 4)$ the difference between the individual's income and the regional (subsistence) income (income). In general, using a regional or national reference level is advantageous in that it is exogenously given for the single individual.

Because any differences resulting from variations in the reference income might be interesting, we not only investigate the relationship between the relative income position and social capital at subsistence level and on average, we also employ a regional and national income benchmark model. The subsistence level as the benchmark income is expected to mirror the shape of a utility function ${ }^{4}$, while the average income seems intuitively more appealing for social comparison. The regional factor takes into account that income levels are not equally distributed within countries and people are more likely to compare their societal

\footnotetext{
${ }^{2}$ Tables A1-A2 in the appendix provide a complete list of the dependent variables and the determinants.

${ }^{3} \mathrm{We}$ are aware that cross-sections are subject to problems like endogeneity. Using individual data has the advantage that at least the macro determinants are not influenced by the behaviour of one single individual.

${ }^{4}$ This concept assumes that positive utility levels are attached to income at least as high as the subsistence level, which is not necessarily the case for income below this threshold.
} 
position with that of close neighbours than with the rest of the world (Festinger, 1954; Stouffer, 1949). Moreover, without strong migration incentives to move between regions with different general levels of wealth, positional concerns and envy effects should be stronger for the regional benchmark model. One important, but often neglected, control variable is cultural background, which we proxy by language. ${ }^{5}$

Equation (1) is estimated with a weighted ordered probit estimation method; clustering at the regional or national level takes into account that the error terms of individuals living in the same country or region might be correlated because identical institutions and conditions are shared, which might otherwise bias the standard errors of the coefficients downward (Moulton, 1990). Application of weights makes the estimation results representative for the corresponding national population.

The set of income variables allows differentiation between the absolute and relative income hypothesis. If only relative income matters, the coefficient of the average or subsistence income should be zero. If absolute income matters, the coefficients of the reference group and the relative income should be both positive and identical. To test the relative income hypothesis against the absolute income hypothesis, we conduct a Wald-test on the difference between the two relevant coefficients after each regression. In addition, because the estimated coefficients only indicate the direction of the effect not its magnitude, we also compute marginal effects for the highest level of social capital.

Finally, it can be argued that income comparisons are asymmetric (Ferrer-i-Carbonell, 2005; Duesenberry, 1949; Holländer, 2001; Frank, 1985). Therefore, the non-linearity of the effect of income on social capital is taken into account by the squared terms $\operatorname{diff} 2$ pos $^{6}$ and diff $2 n e g^{7}$. It may well be that individuals below the reference income are more strongly

\footnotetext{
${ }^{5}$ We form five cultural supra-national groups: Germanic languages, Northern Germanic languages, Balto-Slavic languages, and other non-English language. The reference category is English-speaking nations.

${ }^{6}$ diff 2 pos $=$ square term of difference if difference $>0$ otherwise 0.

${ }^{7}$ diff2neg $=$ square term of difference if difference $<0$, otherwise 0.
} 
influenced by the relative income position, which leads to the expectation of a decreasing marginal utility of income for richer, but not poorer, individuals.

\section{Estimation Results}

\subsection{Regional Income as a Benchmark of Comparison}

\section{Happiness}

Table 1 reports the results for the case in which the regional subsistence income level serves as an individual's benchmark for evaluating his or her relative income position. Table 1a, specifically, presents the results when regional average income is employed. The first dependent variable is our generic measure of 'happiness', which assumes that a higher level of social trust, better networks and well-targeted government activities may be transmission channels for citizen well-being. This dependent variable measures respondent happiness in four categories, with the highest category indicating the highest level of happiness. ${ }^{8}$ The results reveal that individual well-being not only rises with the regional subsistence level but also, and more significantly, with an increase in the relative income position. The marginal effects are relatively high, indicating a strong impact of difference and income with a probability of reporting the highest happiness level of 6.6 and 4.7 percentage points. Thus, the results indicate not only that absolute income level matters but that the relative income position is also important, which is in line with our hypothesis 1 and several previous findings in the happiness literature.

\footnotetext{
${ }^{8}$ Original question: "If you were to consider your life in general these days, how happy or unhappy would you say you are, on the whole". Possible answers were "very happy", fairly happy", "not very happy" and "not at all happy".
} 
The size of the marginal effects is one of the largest among the investigated measures of social capital, which indicates that our benchmark variable, happiness, provides one of the strongest position concern effects. Moreover, the negative sign of the positive difference squared indicates a decreasing marginal utility in income. Nevertheless, the Wald-test does not reject the null hypothesis of equal coefficients for the two main income variables, which suggests that the absolute income level matters for happiness when the comparison income is the regional subsistence level. Table 1a also shows the estimation results and findings to be almost identical when the regional average income, rather than the subsistence level income, is employed. Only the marginal effect of relative income appears to be somewhat smaller (0.044 compared to 0.066), which can be assumed to reflect the fact that the distance between an individual's income and the subsistence level is always greater than that between individual earnings and the higher average income. Thus, overall, these findings are consistent with the first hypothesis that a relatively worse income level decreases happiness.

\section{Generalized Trust}

The next set of regressands relates to generalized trust, the dimension of social capital that measures whether respondents believe that people in general can be trusted and how they evaluate the general level of fairness in society. The first question, related to generalized trust, asks respondents to assess the general degree of other people's fairness towards themselves. ${ }^{9}$ A low value for the categorical regressand reflects the view that 'people take advantage all the time', whereas the highest value indicates the answer 'people are fair all the time'. In partial support of hypothesis 2 , the regression outcome shows that perceived fairness increases with both the general income level and an individual's relative income position. The marginal

\footnotetext{
${ }^{9}$ Original question: "How often do you think that people would try to take advantage of you if they got the chance and how often would they try to be fair?". Possible answers were "try to take advantage of me all of the time", "try to take advantage most of the time", "try to be fair most of the time" or "try to be fair almost all of the time".
} 
effects also vary substantially between 5.1 (income) and 3.4 percentage points (difference) for the highest level of social capital.

The non-rejection of the Wald-test provides evidence that it is the absolute individual income that matters most. The richer the individuals, the more they perceive others as acting fairly; in other words, envy generated by low levels of absolute income destroys social trust. For positive income differences, a decreasing marginal social capital of income is observable. In contrast, when the regional average income is used as the benchmark income, it is only the overall level of wealth in the society - no longer the relative income position - that positively affects social capital. Accordingly, the marginal effect of the average income (3.4 percentage points) is still substantial, but that for the relative income is considerably lower $(0.8$ percentage points). However, in this case, the Wald-test on the income variables does not support the absolute income hypothesis.

The second question asks whether people can generally be trusted or whether individuals should be careful. ${ }^{10}$ Again, the lowest category indicates a low level of trust. The regional average income level does not appear decisive for the trust level, but trust increases with an increase in the relative income position, which supports the impact of positional concerns. That is, the richer people are relative to their peers, the more they regard their environment as trustworthy. Thus, it is not the absolute but the relative level that apparently affects generalized trust. Moreover, the marginal effects are not negligible with 1.8 percentage points for the highest category. Nevertheless, the Wald-test on the income variables again fails to support the relative income hypothesis. For negative differences in income, the coefficient reveals an increasing marginal trust; whereas for positive differences, the estimate indicates a decreasing marginal trust. However, given the alternative income benchmark, both relative and absolute income become decisive and positive determinants of social trust. This

\footnotetext{
${ }^{10}$ Original question: "Generally speaking, would you say that people ca be trusted or that you can't be too careful in dealing with people?" Possible answers were "people can almost be trusted", "people can usually be trusted", "you usually can't be too careful in dealing with people" or "you almost always can't be too careful in dealing with people".
} 
result very much resembles that obtained for the alternative trust measure, yet with a focus on the regional subsistence level. Notwithstanding, the Wald-tests' support of the absolute income hypothesis contradicts the observed significances of the coefficients.

Overall, the results for the two trust variables are mixed as to whether the absolute or relative income hypothesis holds. In general, positional concerns appear strong and are quantitatively stronger when the regional subsistence level, rather than the regional average level, is used as the benchmark income. This finding strongly suggests that hypothesis 2 cannot be rejected.

\section{Trust in State Institutions}

The third set of dependent variables measures the confidence in state institutions specifically, the parliament, courts, business and the church - that represents the quality of the relationship between government and the respondent. Again, higher values for these variables indicate a higher level of confidence. ${ }^{11}$

Confidence in parliament is influenced by neither the general wealth of a society nor the relative income position of an individual. Nor, however, does confidence in courts depend on regional subsistence level. Rather, it is positively related to the relative income position: the relatively richer the individuals, the more they trust the country's courts (and justice system). This outcome supports hypothesis 3 . That is, envy appears to destroy public trust in institutions that the population assumes act more independently and more objectively than other institutions subject to political business and re-election cycles. For the highest trust level, the marginal effects are about 2 percentage points.

Nevertheless, the Wald-test on the income variables cannot fully support the relative income hypothesis. Indeed, the results presented in Table 1a paint a totally different picture:

\footnotetext{
${ }^{11}$ Original question: "How much confidence do you have in ....(1) parliament (2) business and industry (3) churches and religious organizations (4) courts and the legal system". Possible answers were "complete confidence", "a great deal of confidence", "some confidence", "very little confidence" or "no confidence at all".
} 
that is, the confidence in parliament clearly rises with regional income and also (weakly) with relative income position. The Wald-test on the income variables supports the absolute income hypothesis and the subjective view that better institutions are found in wealthier nations. With respect to the confidence in courts, the decisiveness of the positional concerns is supported by the Wald-test evidence for the relative income hypothesis, which supports hypothesis 3 . In addition, the marginal effect of the relative income variable of 2.6 percentage points is stronger by far than that observed for the regional subsistence income (about 1.5 percentage points). However, in addition to the results in Table 1, the decreasing marginal confidence in the courts associated with a positive income distance possibly mirrors the decreasing marginal benefit of a well-functioning court system for persons above the regional average income.

The measure 'confidence in business' appears unaffected by the level of regional economic development but increases with the distance between individual income and the regional subsistence level. Thus, positional concerns matter in the business arenas in which many individuals take part daily. However, yet again, the Wald-test results for the income variables do not support the relative income hypothesis. In line with our expectations (hypothesis 4), confidence in the church is completely unrelated to any income level (either absolute or relative). Thus, there is no positional concern effect on this institution, possibly reflecting its (presumably) non-profit nature.

When the regional average income is used instead of the regional subsistence level (see Table 1a), the findings are quite similar, particularly for the confidence in churches. As regards the variable 'confidence in business', the average level of economic development appears to gain a weak positive momentum, but, on the other hand, the Wald-test now weakly rejects the absolute income hypothesis. Therefore, positional concerns appear better supported when the average income serves as a benchmark income, possibly because it tends to be the common comparison income in the business arena. Results for confidence in churches remain unchanged. 
In sum, trust in the parliament appears to be driven by absolute wealth, but trust in courts and business, by the relative income position. Thus, the results are only partly consistent with hypothesis 3 . On the other hand, trust in churches is independent of any type of income, which is in line with hypothesis 4.

\section{Compliance with Social Norms}

The next dimension of social capital, compliance with norms, is measured by tax morale, government benefit morale and the subjective right of a friend to unlawful testimony as protection against state prosecution.

The first regressand, the 'tax morale' measure, relates to the respondent's view on whether it is morally wrong to report income taxes incorrectly. ${ }^{12}$ The lowest category reflects the answer "not wrong", while the highest category indicates "seriously wrong". The estimates show that the overall regional income level has no impact on tax morale but that the level of incorrect reporting appears to increase with the distance between the individual's equivalent income and the regional subsistence level. In other words, the closer people's own earnings are to the subsistence level, the more prone they are not to report income taxes correctly. Thus, as predicted in hypothesis 5, envy and positional concerns on the part of the deprived decreases social capital in the form of tax morale. Interestingly, the income difference apparently exerts a considerable marginal effect on the highest tax morale (about 3.9 percentage points).

These results indicate that envy factors must be taken into account during tax system design and consideration of the relationship between taxpayers and the government (tax administration, in particular). The positive and weakly significant coefficient on the negative difference squared even suggests that the marginal tax morale increases with relative income

\footnotetext{
${ }^{12}$ Original question: "Consider the situations listed below. Do you feel it is wrong or not wrong if...a taxpayer does not report all of [his/her] income in order to pay less income tax". Possible answers were "not wrong", " a bit wrong", "wrong" and "seriously wrong".
} 
for persons below the subsistence level. Nevertheless, because the Wald-test cannot reject the hypothesis of equal coefficients for both the subsistence and difference incomes, the absolute income hypothesis cannot be completely rejected. Again, using the regional average income instead of the subsistence level produces fairly similar estimation outcomes. The sole difference is that the coefficient of the negative distance squared (diff2neg) loses its significance, whereas the negative coefficient of the positive distance squared (diff2pos) becomes statistically significant at the 10 percent level. These estimates indicate that the propensity to report taxes honestly increases with an increase in relative income position, but at a decreasing rate.

In the case of the second measure for compliance with social norms - whether it is morally wrong to give incorrect information to obtain government benefits ${ }^{13}-$ we observe that acceptance of cheating the government decreases with overall wealth as measured by the regional subsistence income. In addition, acceptance also declines with an increasing distance between the individual's income and the regional subsistence level. In other words, the lower the individual's relative income position, the higher the propensity to cheat the government, thereby, in line with hypothesis 5, destroying social capital. We also observe very high marginal effects -10.3 percentage points for the highest compliance level. Moreover, the negative coefficient on the positive difference squared indicates a decreasing marginal propensity for compliance by those whose incomes are above the subsistence level. For this case, the Wald-tests indicate that the equality of the income variable coefficients cannot be rejected, meaning that the absolute income hypothesis seems to be supported. That is, social capital as measured by acceptance of cheating the government to obtain benefits decreases with absolute income level. Again, using the regional average income changes the results very

\footnotetext{
${ }^{13}$ Original question: "Do you feel it is wrong or not wrong if a person gives the government incorrect information about [himself/herself] to get government benefits that [he/she] is not entitled to". The range of possible answers is the same as in the preceding footnote.
} 
little; only the Wald-test on the income variables now supports the relative income hypothesis at the 10 percent level and equally rejects it at the 5 percent level.

In the case of the regressand for the third social norm - whether close friends have the right to give wrongful testimony aimed at lowering their punishment - the lowest category reflects the answer "he has a definite right" and the highest, "he has no right". ${ }^{14}$ Interestingly, both wealth in society and a better relative individual income position appear deleterious to the perceived rights of a friend, thereby positively affecting obeisance to the law. This result might reflect perception of the state in poor countries as an opponent of the people, meaning that willingness not to comply with the rules is more widespread. However, when the distance between individual income and subsistence level is positive, the second derivative appears to be negative - that is, against obedience to the law. In this estimation, the Wald-test on the income variables is more in favour of the absolute income hypothesis, which contradicts hypothesis 5. Specifically, an increase in absolute income is associated with an increase in compliance with the law. When the reference income is changed, the coefficient of the absolute wealth level becomes strongly significant; however, the significance level of the income distance variable completely breaks down. Again, even though the Wald-test does not reject the null hypothesis of equal coefficients, absolute income seems to matter for propensity to comply with the law.

Overall, the results obtained for the social norm 'compliance' indicate an overall tendency for hypothesis 5 not to be rejected. However, the importance of positional concerns varies among the variables investigated.

\section{Social Networks}

\footnotetext{
${ }^{14}$ The questionnaire describes the following situation: "Suppose you were riding in a car driven by a close friend. You know he is going too fast. He hits a pedestrian. He asks you to tell the police that he was obeying the speed limit. Which statement comes closest to your belief about what your friend has a right to expect from you?". Possible answers were "My friend has a DEFINITE right as a friend to expect me to testify that he was obeying the speed limit", "My friend has SOME right as a friend to expect me to testify that he was obeying the speed limit" or "My friend has NO right as a friend to expect me to testify that he was obeying the speed limit".
} 
The last set of regressands is linked to social networks that form a decisive part of social capital. These are measured particularly by the frequency of the interviewee's voluntary participation in politics, charitable activities, religious activities and other kinds of voluntary work. Again, a higher value for the dependent variable reflects more frequent involvement in such activities. $^{15}$

The regression results shows no influence of the regional subsistence level on the propensity to engage in voluntary work in politics. Moreover, the coefficient on the relative income position is weakly significant at the 10 percent level, indicating that persons with a relatively lower income than their peers are more politically active. Such involvement may occur because political engagement can serve as a means to improve one's own social position through rent-seeking activities, gains in reputation and influence on the political decision-making process. This finding supports hypothesis 6. Since the Wald-test does not reject the equality of the income variable coefficients, the absolute income level might also be decisive. For positive differences in income, the second derivative appears to be positive, indicating an increasing marginal activity level of income. However, employing the regional average income as a benchmark yields a completely different picture (see Table 1a) - neither the absolute wealth level nor positional concerns appear to matter for political engagement. Only the marginal propensity shows an apparent increase for positive income differences, although weakly and only at the 10 percent significance level.

As the significant coefficient on the regional subsistence level indicates, voluntary work in charity organizations such as the Red Cross and the Salvation Army appears to increase with overall social wealth. On the other hand, as for political involvement, the

\footnotetext{
${ }^{15}$ Related question: "Have you done any voluntary activity in the last 12 months in any of the following areas? Voluntary activity is unpaid work, not just belonging to an organization or group. It should be of service or benefit to other people or the community and not only to one's family or personal friends. During the last 12 months, did you do volunteer work in any of the following areas: (a) Political activities (helping political parties, political movements, election campaigns, etc.), (b) charitable activities (helping the sick, elderly, poor, etc.), (c) religion and church-related activities (helping churches and religious groups), and (d) any other kind of voluntary activities?". Possible answers were (1) no, (2), yes, once or twice, (3) yes, 3-5 times, (4) yes, 6 or more times. When answering these questions, respondents were asked to list one voluntary activity only once, even when several categories might apply.
} 
frequency of such activities decreases with an increase in the relative income position but with much higher marginal effects (2.1 percentage compared to 0.4 percentage points). Nevertheless, the Wald-test on the two income variables supports the view that it is the relative income position and not the absolute individual income level that matters. Obviously, no detrimental effect of envy exists here; rather, as predicted by hypothesis 6 , persons with a low or middle relative income position become socially active. Admittedly, those with a higher income may face tighter time constraints; however, it might also be that persons with a relatively low income prefer to actively engage in a cooperative re-distributive equilibrium activity among their peers rather than support such organizations financially. In addition, for this dimension of social capital, we observe that the estimation results are comparable to those based on the regional average income. The only difference is that for positive income distances the propensity to become socially active decreases, but at an increasing rate.

Religious activities seem to increase with the absolute (regional) subsistence level. The wealthier a region, the more active people are in voluntary work for religious organizations. In contrast, the relative income position does not appear to matter at all, which contradicts hypothesis 6 . Nevertheless, the Wald-test on the income variables is rather in favour of the relative income hypothesis. It is noteworthy that a change in the reference income brings positional concerns into more prominence; that is, relatively richer persons now have a lower propensity to become involved in religious organizations. Moreover, the Wald-test still favours the relative income hypothesis. In addition, the negative income distance squared becomes now weakly statistically significant at the 10 percent level. In other words, the observed pattern is very similar to that for engagement in charity organizations.

Finally, the frequency of activities in other kinds of voluntary work appears to increase with the regional level of economic wealth, although the distance between individual income and the regional subsistence level does not appear to influence such involvement. Hence, such activity seems not to be influenced by envy. Nevertheless, the Wald-test on the income 
variables somewhat supports the relative income hypothesis. Interestingly, positive differences in income have a negative marginal value of relative income, indicating less social engagement. Moreover, results based on the regional average income, rather than the subsistence level (see Table 1a), indicate that the relative income position then becomes decisive (at the 5 percent level), which is also supported by the Wald-test. Specifically, the coefficient indicates that a higher relative position in society leads to fewer volunteer activities. Thus, in this specification, the coefficient on the second income derivative becomes an unimportant factor.

Overall, for social engagement in charity, religious or other organizations, relative income becomes decisive when the regional average income rather than the regional subsistence level is used as the benchmark. In contrast, when the focus is on the subsistence level rather than the relative income position, only the general wealth level appears to matter for religious and other social engagement. Under both benchmark specifications, political activities alone appear somewhat related to absolute or relative individual income position. Thus, it can be argued that these estimation results are only partially consistent with hypothesis 6.

\subsection{National Income as the Benchmark of Comparison}

By outlining the estimates for both the subsistence and average incomes measured at the national level, Tables 2 and 2a illustrate the different results when the reference group is changed - that is, when the relative individual income position is measured with respect to the national rather than the regional situation. The following discussion focuses particularly on these differences, with the regional income as the income of comparison.

The results for happiness are almost the same for both national subsistence and average income with respect to direction of influence, significance levels and the Wald-test on 
income variables. Again, the size of the marginal impact of the relative income position declines when the average income measure serves as the benchmark income. As regards the variables relating to level of social trust among the country's residents, the observed impacts of the subsistence level and relative income position variables are again virtually identical for both incomes, which holds equally true for the estimated squared terms. In addition, the marginal effects are quantitatively consistent, with a certain decline in the average income impact for both regional and national cases but no clear tendency for positional concerns to work more strongly in the regional than in the national context.

For trust in institutions, the direction of the (significant) income variables' impact on the four measures is more or less as observed for the regional case. Identical results are obtained for confidence in the church (in which income never plays a role) and confidence in business, for which an increase in significance level is again observed when average income in place of subsistence income is used.

Differences do emerge, however, with respect to trust in parliament and the courts. For confidence in parliament, some changes occur in the significance levels but only at the 10 percent level. Most particularly, relative income position seems to matter for both regional average income (Table 1a) and national subsistence level (Table 2), but not for the other two cases. This result indicates that envy is weakly associated with a lower level of confidence in the legislating institution. With respect to confidence in courts, a higher national subsistence income is associated with less confidence, while the national average income variable is insignificant. Interestingly, this result does not replicate the results for regional income, in which general wealth is apparently never decisive. Again however, the relative income position always matters, and the smallest marginal effect and lowest significance level occur when the subsistence income is used. In this case, the Wald-test supports the absolute income hypothesis, even though for the remaining regressions on court confidence the relative income hypothesis holds. 
As regards compliance with social norms, for the tax and benefit morale questions, we report qualitatively identical results for the income variables in all four models except for a 10 percent significance level for the diff2pos variable when the regional average income is used. The marginal impacts of the relative income position are comparably large for all four regression models, and the Wald-tests cannot reject the null hypothesis in any model. However, when the right of a friend is the regressand and the national subsistence level is used, the relative income position - unlike the regional subsistence level which is significant at the 5 percent level - misses significance at the 10 percent level. The remaining results, however, are robust no matter which income is used.

When the focus is social networks (frequency of participation in voluntary work), the income variables based on the national subsistence level show exactly the same pattern and similar quantitative effects as those for the regional benchmark model. In addition, the size of the income impact is almost identical when the national concept is employed, with the sole exception of a 10 percent significance of diff $2 p o s$ in the voluntary political involvement regression model (Table 1a).

In sum, looking at both benchmark models, we find in many cases that, in line with Ferrer-i-Carbonell (2005), income comparisons are not symmetric and any income effect is not per se linear. There is also a stronger tendency towards decreasing marginal utility for incomes above the subsistence level than for those below. Moreover, the findings using two different reference groups are robust and consistent: the estimation outcome does not change substantially no matter whether regional or national income variables are employed. Thus, in terms of a stronger envy or positional concern effect, we observe no general tendency when the regional benchmark model is used. Moreover, for most social capital dimensions, the direction of impact is consistent whether the subsistence level or average income situation is used as a reference. Differences do occur, however, with respect to the marginal impact, which appears larger when the subsistence level is employed as the benchmark income. 


\section{Conclusion}

The importance of relative preferences is not a new concept. However, empirical evidence on the extent to which relative income position matters in different aspects of life is relatively rare. Moreover, most empirical studies to date focus on its impact on happiness. Nevertheless, two laboratory experiments have investigated the consequences of positional concerns for individuals' social behaviour (see, e.g., Kirchsteiger, 1994), and some field studies indicate the influence of relative income position on, for example, employer performance or employment decisions (see, e.g., Torgler et al., 2005; Neumark and Postlewaite, 1998).

Paldam (2000) correctly points out that the social capital literature is a "new field, [but] suffering from a great lack of good, reliable data. Both time series and cross-country evidence are missing. In the meantime much speculation is going on" (p. 649). This current international cross-sectional study, using the rich ISSP 1998 international data covering 25 countries and about 24,000 individuals, goes beyond several previous studies that, because they focus on a single country, are unable to abstract the impact of cultural differences. Thus, our paper contributes to the social capital literature in general and the cross-sectional research in particular by (1) analyzing the impact of relative income position on social capital and (2) using 14 different questions to measure social capital along four different dimensions: general trust between people, trust in institutions, compliance with social norms and voluntary activities. We also include self-reported happiness, which serves as our benchmark measure.

In general, we find empirical support for relative income position's relevance for social capital. In most cases, we find the coefficient measuring an interviewee's relative income position statistically significant, with considerable marginal effects. Only compliance with criminal law (e.g. giving wrong testimony to protect a friend), confidence in parliament, and voluntary work for political, religious or other organizations appear to be (at least partly) free of positional concerns, at least in some model specifications. Most particularly, 
confidence in churches appears unrelated to either average wealth or relative income, independent of reference income measurement.

The social capital measures most strongly affected quantitatively by the relative income position include compliance with social norms (e.g. paying taxes or not unjustifiably claiming government benefits) and generalized trust (with a marginal effect up to 10 percentage points). For all these measures, social capital rises with relative income or, in other words, declines with growing envy. We also find substantial effects for trust in the courts and the justice system, institutions which are less related than some others to the current politicoeconomic process. Obviously, these institutions, like the important environments of business and industry in which many citizens interact and work in their daily life, are more vulnerable to an envy effect. As regards individual participation in voluntary organizations, when an income disadvantage exists (compared to the reference income), a stronger effect of the relative income position become prominent, together with stronger social involvement.

For most models, it is also impossible to completely reject either the relative or the absolute income hypothesis. Moreover, in many cases, we find evidence that the relative income effect is not symmetrical with or linear to the tendency of decreasing marginal utility for incomes above the reference level. Most surprisingly, the majority of findings are consistent even in the absence of qualitatively different effects for one specific benchmark model: that is, most results are fairly robust to a change in reference groups - national versus regional and subsistence versus average income level. Only the marginal impacts of the positional variable appear more sizeable when the subsistence income serves as the reference income. 


\section{Tables}

Table 1

Regional Subsistence Income as a Benchmark for Social Comparison: Social Trust

\begin{tabular}{lllllll}
\hline & Happiness & & \multicolumn{3}{c}{ Advantage } & \multicolumn{3}{c}{$\begin{array}{l}\text { Generalized } \\
\text { trust }\end{array}$} \\
& Coeff. & Marg. eff. & Coeff. & Marg. eff. & Coeff. & Marg. eff. \\
\hline Income & $0.195^{*}$ & 0.047 & $0.226^{*}$ & 0.051 & 0.084 & 0.006 \\
& $(2.25)$ & & $(2.55)$ & & $(0.90)$ & \\
Difference & $0.272^{* *}$ & 0.066 & $0.150^{*}$ & 0.034 & $0.242^{* *}$ & 0.018 \\
& $(4.40)$ & & $(2.18)$ & & $(4.12)$ & \\
diff2neg & -1.009 & -0.245 & 0.413 & 0.093 & $1.605\left(^{*}\right)$ & 0.120 \\
& $(0.92)$ & & $(0.54)$ & & $(1.69)$ & \\
diff2pos & $-0.058^{* *}$ & -0.014 & $-0.040\left(^{*}\right)$ & -0.009 & $-0.057^{* *}$ & -0.004 \\
& $(2.81)$ & & $(1.84)$ & & $(3.01)$ & \\
\hline Observations & 24166 & & 22509 & & 24290 & \\
\hline Wald-test & & & & & & \\
(income-difference) & 0.43 & & 0.29 & & 0.232 & \\
Prob > chi2 & 0.5141 & & 0.5872 & & 0.0623 & \\
Pseudo R2 & 0.0790 & & 0.0493 & & \\
\hline Orded & & & & & & \\
\hline
\end{tabular}

Ordered probit estimation with clustering by regions. Marginal effects calculated at the average for the highest category of the social capital variable. ${ }^{*}, * *$, and $(*)$ denote significances at the $1-, 5-$, and 10 -percent levels, respectively.

Table 1a

Regional Average Income as Benchmark for Social Comparison: Social Trust

\begin{tabular}{lllllll}
\hline & Happiness & & Advantage & \multicolumn{3}{c}{$\begin{array}{l}\text { Generalized } \\
\text { trust }\end{array}$} \\
& Coeff. & Marg. eff. & Coeff. & Marg. eff. & Coeff. & Marg. eff. \\
\hline Income & $0.186^{* *}$ & 0.045 & $0.152^{* *}$ & 0.034 & $0.128^{* *}$ & 0.010 \\
& $(4.95)$ & & $(5.11)$ & & $(3.78)$ & \\
Difference & $0.179^{* *}$ & 0.044 & 0.037 & 0.008 & $0.144^{* *}$ & 0.011 \\
& $(4.44)$ & & $(0.62)$ & & $(2.75)$ & \\
diff2neg & 0.012 & 0.003 & -0.06 & -0.013 & 0.032 & 0.002 \\
& $(0.22)$ & & $(0.99)$ & & $(0.45)$ & \\
diff2pos & $-0.049^{* *}$ & -0.012 & -0.022 & -0.005 & $-0.055\left(^{*}\right)$ & -0.004 \\
& $(2.83)$ & & $(0.67)$ & & $(1.84)$ & \\
\hline Observations & 24166 & & 22509 & & 24290 & \\
\hline Wald-test & & & & & & \\
(income-difference) & 0.01 & & $2.98\left(^{*}\right)$ & & 0.06 & \\
Prob $>$ chi2 & 0.9165 & & 0.0841 & & 0.8140 & \\
Pseudo R2 & 0.6787 & & 0.0492 & & 0.0621 & \\
\hline Orded probit & & & & & \\
\hline
\end{tabular}

Ordered probit estimation with clustering by regions. Marginal effects calculated at the average for the highest category of the social capital variable. *, **, and $\left(^{*}\right)$ denote significances at the 1-, 5-, and 10-percent levels, respectively. 
Table 1 (cont.)

Regional Subsistence Income: Confidence in State Institutions

\begin{tabular}{|c|c|c|c|c|c|c|c|c|}
\hline & \multicolumn{2}{|l|}{ Parliament } & \multicolumn{2}{|l|}{ Courts } & \multicolumn{2}{|l|}{ Business } & \multicolumn{2}{|l|}{ Church } \\
\hline & Coeff. & $\begin{array}{l}\text { Marg. } \\
\text { eff. }\end{array}$ & Coeff. & $\begin{array}{l}\text { Marg. } \\
\text { eff. }\end{array}$ & Coeff. & $\begin{array}{l}\text { Marg. } \\
\text { eff. }\end{array}$ & Coeff. & $\begin{array}{l}\text { Marg. } \\
\text { eff. }\end{array}$ \\
\hline Income & $\begin{array}{l}0.036 \\
(0.57)\end{array}$ & 0.010 & $\begin{array}{l}-0.105 \\
(1.25)\end{array}$ & -0.023 & $\begin{array}{l}-0.049 \\
(0.76)\end{array}$ & -0.010 & $\begin{array}{l}-0.094 \\
(1.21)\end{array}$ & -0.023 \\
\hline Difference & $\begin{array}{l}0.078 \\
(1.54)\end{array}$ & 0.021 & $\begin{array}{l}0.070^{*} \\
(2.09)\end{array}$ & 0.015 & $\begin{array}{l}0.101^{*} \\
(2.10)\end{array}$ & 0.020 & $\begin{array}{l}-0.02 \\
(0.48)\end{array}$ & -0.005 \\
\hline diff2neg & $\begin{array}{l}0.716 \\
(1.03)\end{array}$ & 0.190 & $\begin{array}{l}-0.211 \\
(0.31)\end{array}$ & -0.046 & $\begin{array}{l}-0.103 \\
(0.12)\end{array}$ & -0.020 & $\begin{array}{l}-0.765 \\
(0.96)\end{array}$ & -0.184 \\
\hline diff $2 p o s$ & $\begin{array}{l}-0.017 \\
(1.15) \\
\end{array}$ & -0.005 & $\begin{array}{l}0.001 \\
(0.06) \\
\end{array}$ & 0.000 & $\begin{array}{l}-0.004 \\
(0.25) \\
\end{array}$ & -0.001 & $\begin{array}{l}0.003 \\
(0.25) \\
\end{array}$ & 0.001 \\
\hline Observations & 23690 & & 23810 & & 23279 & & 23615 & \\
\hline $\begin{array}{l}\text { Wald-test } \\
\text { (income - difference) }\end{array}$ & 0.15 & & 2.64 & & 2.15 & & 0.52 & \\
\hline Prob $>$ chi2 & 0.6970 & & 0.1040 & & 0.1424 & & 0.4719 & \\
\hline Pseudo R2 & 0.0056 & & 0.0057 & & 0.0056 & & 0.0097 & \\
\hline
\end{tabular}

Table 1a (cont.)

Regional Average Income: Confidence in State Institutions

\begin{tabular}{|c|c|c|c|c|c|c|c|c|}
\hline & \multicolumn{2}{|c|}{ Parliament } & \multicolumn{2}{|l|}{ Courts } & \multicolumn{2}{|l|}{ Business } & \multicolumn{2}{|l|}{ Church } \\
\hline & Coeff. & Marg. eff. & Coeff. & Marg. eff. & Coeff. & $\begin{array}{l}\text { Marg. } \\
\text { eff. }\end{array}$ & Coeff. & Marg. eff. \\
\hline Income & $\begin{array}{l}0.044 * * \\
(2.68)\end{array}$ & 0.012 & $\begin{array}{l}-0.001 \\
(0.02)\end{array}$ & -0.001 & $\begin{array}{l}0.037\left(^{*}\right) \\
(1.82)\end{array}$ & 0.007 & $\begin{array}{l}-0.044 \\
(1.51)\end{array}$ & -0.011 \\
\hline Difference & $\begin{array}{l}0.062\left(^{*}\right) \\
(1.72)\end{array}$ & 0.017 & $\begin{array}{l}0.119^{* *} \\
(5.03)\end{array}$ & 0.026 & $\begin{array}{l}0.107^{* *} \\
(3.01)\end{array}$ & 0.021 & $\begin{array}{l}-0.025 \\
(0.72)\end{array}$ & -0.006 \\
\hline diff2neg & $\begin{array}{l}0.034 \\
(0.60)\end{array}$ & 0.009 & $\begin{array}{l}0.046 \\
(1.37)\end{array}$ & 0.010 & $\begin{array}{l}0.016 \\
(0.28)\end{array}$ & 0.003 & $\begin{array}{l}-0.032 \\
(0.58)\end{array}$ & -0.008 \\
\hline diff2pos & $\begin{array}{l}-0.022 \\
(1.34)\end{array}$ & -0.006 & $\begin{array}{l}-0.026^{*} \\
(2.46) \\
\end{array}$ & -0.006 & $\begin{array}{l}-0.008 \\
(0.45)\end{array}$ & -0.002 & $\begin{array}{l}0.007 \\
(0.49)\end{array}$ & 0.002 \\
\hline Observations & 23690 & & 23810 & & 23279 & & 23615 & \\
\hline $\begin{array}{l}\text { Wald-test } \\
\text { (income - difference) }\end{array}$ & 0.16 & & $8.09 * *$ & & $2.77(*)$ & & 0.13 & \\
\hline Prob $>$ chi2 & 0.6850 & & 0.0044 & & 0.0961 & & 0.7157 & \\
\hline Pseudo R2 & 0.0056 & & 0.0057 & & 0.0056 & & 0.0097 & \\
\hline
\end{tabular}


Table 1 (cont.)

Regional Subsistence Income: Compliance with Social Norms

\begin{tabular}{|c|c|c|c|c|c|c|}
\hline & \multicolumn{2}{|c|}{ Tax morale } & \multicolumn{2}{|c|}{ Benefit morale } & \multicolumn{2}{|c|}{ Right of friend } \\
\hline & Coeff. & Marg. eff. & Coeff. & Marg. eff. & Coeff. & Marg. eff. \\
\hline Income & 0.003 & 0.001 & $0.288^{*}$ & 0.114 & $0.219\left(^{*}\right)$ & 0.070 \\
\hline & $(0.03)$ & & (2.28) & & $(1.70)$ & \\
\hline Difference & $0.107^{*}$ & 0.039 & $0.260^{* *}$ & 0.103 & $0.120^{*}$ & 0.038 \\
\hline & (2.56) & & $(4.78)$ & & $(2.11)$ & \\
\hline diff2neg & $0.741\left(^{*}\right)$ & 0.270 & -0.183 & -0.072 & -1.158 & -0.370 \\
\hline & (1.71) & & $(0.32)$ & & $(1.41)$ & \\
\hline $\operatorname{diff} 2 p o s$ & $\begin{array}{l}-0.014 \\
(1.10) \\
\end{array}$ & -0.005 & $\begin{array}{l}-0.056^{* *} \\
(3.24)\end{array}$ & -0.022 & $\begin{array}{l}-0.034^{*} \\
(2.23)\end{array}$ & -0.011 \\
\hline Observations & 23969 & & 24193 & & 22301 & \\
\hline $\begin{array}{l}\text { Wald-test } \\
\text { (income-difference) }\end{array}$ & 0.86 & & 0.04 & & 0.45 & \\
\hline Prob $>$ chi 2 & 0.3529 & & 0.8470 & & 0.5027 & \\
\hline Pseudo R2 & 0.0216 & & 0.0336 & & 0.0539 & \\
\hline
\end{tabular}

Table 1a (cont.)

Regional Average Income: Compliance with Social Norms

\begin{tabular}{lllllll}
\hline & $\begin{array}{l}\text { Tax morale } \\
\text { Coeff. }\end{array}$ & Marg. eff. & $\begin{array}{l}\text { Benefit morale } \\
\text { Coeff. }\end{array}$ & Marg. eff. & $\begin{array}{l}\text { Right of friend } \\
\text { Coeff. }\end{array}$ & Marg. eff. \\
\hline Income & 0.048 & 0.018 & $0.234^{* *}$ & 0.093 & $0.145^{* *}$ & 0.046 \\
& $(1.49)$ & & $(4.65)$ & & $(2.69)$ & \\
Difference & $0.117^{* *}$ & 0.043 & $0.112^{*}$ & 0.044 & 0.0003 & -0.0001 \\
& $(3.45)$ & & $(2.33)$ & & $(0.01)$ & \\
diff2neg & 0.067 & 0.024 & $-0.095\left(^{*}\right)$ & -0.037 & -0.135 & -0.043 \\
& $(1.55)$ & & $(1.87)$ & & $(1.52)$ & \\
diff2pos & $-0.027\left(^{*}\right)$ & -0.010 & $-0.035^{*}$ & -0.014 & -0.014 & -0.004 \\
& $(1.67)$ & & $(2.02)$ & & $(0.65)$ & \\
\hline Observations & 23969 & & 24193 & & 22301 & \\
\hline Wald-test & & & & & $3.73\left(^{*}\right)$ & \\
(income - difference) & 2.17 & & $2.98\left(^{*}\right)$ & & 0.0536 & \\
Prob > chi2 & 0.1410 & & 0.0844 & & 0.0539 & \\
Pseudo R2 & 0.0217 & & 0.0335 & & & \\
\hline
\end{tabular}


Table 1 (cont.)

Regional Subsistence Income: Voluntary Work

\begin{tabular}{|c|c|c|c|c|c|c|c|c|}
\hline & \multirow{2}{*}{$\begin{array}{l}\text { Politics } \\
\text { Coeff. }\end{array}$} & \multicolumn{3}{|c|}{ Charity } & \multirow{2}{*}{$\begin{array}{l}\text { Religion } \\
\text { Coeff. }\end{array}$} & \multicolumn{3}{|c|}{ Other } \\
\hline & & $\begin{array}{l}\text { Marg. } \\
\text { eff. }\end{array}$ & Coeff. & $\begin{array}{l}\text { Marg. } \\
\text { eff. }\end{array}$ & & $\begin{array}{l}\text { Marg. } \\
\text { eff. }\end{array}$ & Coeff. & $\begin{array}{l}\text { Marg. } \\
\text { eff. }\end{array}$ \\
\hline Income & $\begin{array}{l}0.052 \\
(0.43)\end{array}$ & 0.002 & $\begin{array}{l}0.607 * * \\
(3.02)\end{array}$ & 0.076 & $\begin{array}{l}0.572 * * \\
(4.19)\end{array}$ & 0.023 & $\begin{array}{l}0.378^{* *} \\
(3.54)\end{array}$ & 0.049 \\
\hline Difference & $\begin{array}{l}-0.147(*) \\
(1.96)\end{array}$ & -0.004 & $\begin{array}{l}-0.164^{*} \\
(2.21)\end{array}$ & -0.021 & $\begin{array}{l}-0.012 \\
(0.14)\end{array}$ & -0.001 & $\begin{array}{l}0.069 \\
(1.44)\end{array}$ & 0.009 \\
\hline diff2neg & $\begin{array}{l}-0.176 \\
(0.13)\end{array}$ & -0.005 & $\begin{array}{l}-1.784 \\
(1.31)\end{array}$ & -0.223 & $\begin{array}{l}-0.025 \\
(0.02)\end{array}$ & -0.001 & $\begin{array}{l}1.402 \\
(1.43)\end{array}$ & 0.181 \\
\hline diff2pos & $\begin{array}{l}0.047^{*} \\
(2.10)\end{array}$ & 0.001 & $\begin{array}{l}0.026 \\
(1.02) \\
\end{array}$ & 0.003 & $\begin{array}{l}-0.029 \\
(1.13) \\
\end{array}$ & -0.001 & $\begin{array}{l}-0.043 * * \\
(2.62) \\
\end{array}$ & -0.006 \\
\hline Observations & 24362 & & 24396 & & 24330 & & 24172 & \\
\hline $\begin{array}{l}\text { Wald-test } \\
\text { (income - difference) }\end{array}$ & 1.43 & & $10.90^{* *}$ & & $10.51^{* *}$ & & $5.78^{*}$ & \\
\hline Prob $>$ chi2 & 0.2323 & & 0.0010 & & 0.0012 & & 0.0162 & \\
\hline Pseudo R2 & 0.0609 & & 0.0565 & & 0.2149 & & 0.0798 & \\
\hline
\end{tabular}

Table 1a (cont.)

Regional Average Income: Voluntary Work

\begin{tabular}{|c|c|c|c|c|c|c|c|c|}
\hline & \multirow{2}{*}{$\begin{array}{l}\text { Politics } \\
\text { Coeff. }\end{array}$} & \multicolumn{3}{|c|}{ Charity } & \multicolumn{2}{|l|}{ Religion } & \multicolumn{2}{|l|}{ Other } \\
\hline & & $\begin{array}{l}\text { Marg. } \\
\text { eff. }\end{array}$ & Coeff. & $\begin{array}{l}\text { Marg. } \\
\text { eff. }\end{array}$ & Coeff. & $\begin{array}{l}\text { Marg. } \\
\text { eff. }\end{array}$ & Coeff. & $\begin{array}{l}\text { Marg. } \\
\text { eff. }\end{array}$ \\
\hline Income & $\begin{array}{l}-0.043 \\
(0.96)\end{array}$ & -0.001 & $\begin{array}{l}0.164^{*} \\
(2.08)\end{array}$ & 0.021 & $\begin{array}{l}0.203 * * \\
(3.72)\end{array}$ & 0.008 & $\begin{array}{l}0.159 * * \\
(3.58)\end{array}$ & 0.021 \\
\hline Difference & $\begin{array}{l}-0.054 \\
(0.73)\end{array}$ & -0.002 & $\begin{array}{l}-0.221 * * \\
(3.66)\end{array}$ & -0.028 & $\begin{array}{l}-0.176^{*} \\
(2.34)\end{array}$ & -0.007 & $\begin{array}{l}-0.116^{*} \\
(2.21)\end{array}$ & -0.015 \\
\hline diff2neg & $\begin{array}{l}0.073 \\
(0.74)\end{array}$ & 0.002 & $\begin{array}{l}-0.111 \\
(1.03)\end{array}$ & -0.014 & $\begin{array}{l}-0.141\left(^{*}\right) \\
(1.81)\end{array}$ & -0.006 & $\begin{array}{l}-0.099 \\
(1.42)\end{array}$ & -0.013 \\
\hline diff2pos & $\begin{array}{l}0.055\left(^{*}\right) \\
(1.71)\end{array}$ & 0.002 & $\begin{array}{l}0.088^{* *} \\
(3.44) \\
\end{array}$ & 0.011 & $\begin{array}{l}0.036 \\
(1.04) \\
\end{array}$ & 0.001 & $\begin{array}{l}0.019 \\
(0.93)\end{array}$ & 0.002 \\
\hline Observations & 24362 & & 24396 & & 24330 & & 24172 & \\
\hline $\begin{array}{l}\text { Wald-test } \\
\text { (income - difference) }\end{array}$ & 0.02 & & $14.03 * * *$ & & $18.96^{* * *}$ & & $18.49 * * *$ & \\
\hline Prob $>$ chi2 & 0.9011 & & 0.0002 & & 0.0000 & & 0.0000 & \\
\hline Pseudo R2 & 0.0610 & & 0.0568 & & 0.2149 & & 0.0796 & \\
\hline
\end{tabular}


Table 2

National Subsistence Income as the Benchmark for Social Comparison: Social Trust

\begin{tabular}{|c|c|c|c|c|c|c|}
\hline & \multicolumn{2}{|l|}{ Happiness } & \multicolumn{2}{|l|}{ Advantage } & \multicolumn{2}{|c|}{ Generalized trust } \\
\hline & Coeff. & Marg. eff. & Coeff. & Marg. eff. & Coeff. & Marg. eff \\
\hline Income & $\begin{array}{l}0.219^{* *} \\
(2.70)\end{array}$ & 0.053 & $\begin{array}{l}0.206^{*} \\
(2.22)\end{array}$ & 0.046 & $\begin{array}{l}0.058 \\
(0.61)\end{array}$ & 0.004 \\
\hline Difference & $\begin{array}{l}0.260^{* *} \\
(4.47)\end{array}$ & 0.063 & $\begin{array}{l}0.160^{*} \\
(2.29)\end{array}$ & 0.036 & $\begin{array}{l}0.259^{* *} \\
(4.46)\end{array}$ & 0.019 \\
\hline diff2neg & $\begin{array}{l}-0.588 \\
(0.55)\end{array}$ & -0.143 & $\begin{array}{l}0.431 \\
(0.56)\end{array}$ & 0.097 & $\begin{array}{l}1.791\left(^{*}\right) \\
(1.80)\end{array}$ & 0.133 \\
\hline $\operatorname{diff} 2 p o s$ & $\begin{array}{l}-0.054^{* *} \\
(2.79)\end{array}$ & -0.013 & $\begin{array}{l}-0.041\left(^{*}\right) \\
(1.92)\end{array}$ & -0.009 & $\begin{array}{l}-0.061 * * \\
(3.27)\end{array}$ & -0.005 \\
\hline Observations & 24166 & & 22509 & & 24290 & \\
\hline $\begin{array}{l}\text { Wald-test } \\
\text { (income - difference) }\end{array}$ & 0.14 & & 0.10 & & 2.29 & \\
\hline Prob $>$ chi 2 & 0.7117 & & 0.7512 & & 0.1306 & \\
\hline Pseudo R2 & 0.0790 & & 0.0493 & & 0.0623 & \\
\hline
\end{tabular}

Table 2a

National Average Income as the Benchmark for Social Comparison: Social Trust

\begin{tabular}{|c|c|c|c|c|c|c|}
\hline & Happiness & & Advantag & & Generalized & \\
\hline & Coeff. & Marg. eff. & Coeff. & Marg. eff. & Coeff. & Marg. eff. \\
\hline Income & $\begin{array}{l}0.187^{* *} \\
(5.08)\end{array}$ & 0.046 & $\begin{array}{l}0.153^{* *} \\
(5.27)\end{array}$ & 0.034 & $\begin{array}{l}0.131^{* *} \\
(3.79)\end{array}$ & 0.010 \\
\hline Difference & $\begin{array}{l}0.188^{* *} \\
(4.15)\end{array}$ & 0.046 & $\begin{array}{l}0.024 \\
(0.42)\end{array}$ & 0.005 & $\begin{array}{l}0.131^{*} \\
(2.45)\end{array}$ & 0.010 \\
\hline diff2neg & $\begin{array}{l}0.054 \\
(0.76)\end{array}$ & 0.013 & $\begin{array}{l}-0.094 \\
(1.46)\end{array}$ & -0.021 & $\begin{array}{l}-0.009 \\
(0.12)\end{array}$ & -0.001 \\
\hline diff2pos & $\begin{array}{l}-0.048^{*} \\
(2.57)\end{array}$ & -0.012 & $\begin{array}{l}-0.015 \\
(0.52)\end{array}$ & -0.003 & $\begin{array}{l}-0.051\left(^{*}\right) \\
(1.80)\end{array}$ & -0.004 \\
\hline Observations & 24166 & & 22509 & & 24290 & \\
\hline $\begin{array}{l}\text { Wald-test } \\
\text { (income-difference) }\end{array}$ & 0.00 & & $4.20^{*}$ & & 0.00 & \\
\hline Prob $>$ chi 2 & 0.9976 & & 0.0405 & & 0.9992 & \\
\hline Pseudo R2 & 0.0787 & & 0.0492 & & 0.0621 & \\
\hline
\end{tabular}


Table 2 (cont.)

National Subsistence Income: Confidence in State Institutions

\begin{tabular}{|c|c|c|c|c|c|c|c|c|}
\hline & \multicolumn{2}{|l|}{ Parliament } & \multicolumn{2}{|l|}{ Courts } & \multicolumn{2}{|l|}{ Business } & \multicolumn{2}{|l|}{ Church } \\
\hline & Coeff. & $\begin{array}{l}\text { Marg. } \\
\text { eff. }\end{array}$ & Coeff. & $\begin{array}{l}\text { Marg. } \\
\text { eff. }\end{array}$ & Coeff. & $\begin{array}{l}\text { Marg. } \\
\text { eff. }\end{array}$ & Coeff. & $\begin{array}{l}\text { Marg. } \\
\text { eff. }\end{array}$ \\
\hline Income & $\begin{array}{l}0.022 \\
(0.35)\end{array}$ & 0.006 & $\begin{array}{l}-0.160^{*} \\
(2.00)\end{array}$ & -0.035 & $\begin{array}{l}-0.057 \\
(0.85)\end{array}$ & -0.011 & $\begin{array}{l}-0.100 \\
(1.30)\end{array}$ & -0.024 \\
\hline Difference & $\begin{array}{l}0.093(*) \\
(1.89)\end{array}$ & 0.025 & $\begin{array}{l}0.099 * * \\
(3.14)\end{array}$ & 0.021 & $\begin{array}{l}0.107^{*} \\
(2.20)\end{array}$ & 0.021 & $\begin{array}{l}-0.016 \\
(0.36)\end{array}$ & -0.004 \\
\hline diff2neg & $\begin{array}{l}1.042\left(^{*}\right) \\
(1.92)\end{array}$ & 0.277 & $\begin{array}{l}0.072 \\
(0.11)\end{array}$ & 0.016 & $\begin{array}{l}-0.087 \\
(0.10)\end{array}$ & -0.017 & $\begin{array}{l}-0.737 \\
(0.86)\end{array}$ & -0.177 \\
\hline diff2pos & $\begin{array}{l}-0.021 \\
(1.42) \\
\end{array}$ & -0.006 & $\begin{array}{l}-0.006 \\
(0.65)\end{array}$ & -0.001 & $\begin{array}{l}-0.006 \\
(0.39) \\
\end{array}$ & -0.001 & $\begin{array}{l}0.002 \\
(0.14) \\
\end{array}$ & 0.001 \\
\hline Observations & 23690 & & 23810 & & 23279 & & 23615 & \\
\hline $\begin{array}{l}\text { Wald-test } \\
\text { (income - difference) }\end{array}$ & 0.45 & & $6.63 * *$ & & 2.40 & & 0.65 & \\
\hline Prob $>$ chi2 & 0.5015 & & 0.0100 & & 0.1213 & & 0.4211 & \\
\hline Pseudo R2 & 0.0056 & & 0.0057 & & 0.0056 & & 0.0097 & \\
\hline
\end{tabular}

Table 2a (cont.)

National Average Income: Confidence in State Institutions

\begin{tabular}{|c|c|c|c|c|c|c|c|c|}
\hline & \multicolumn{2}{|l|}{ Parliament } & \multicolumn{2}{|l|}{ Courts } & \multicolumn{2}{|l|}{ Business } & \multicolumn{2}{|l|}{ Church } \\
\hline & Coeff. & $\begin{array}{l}\text { Marg. } \\
\text { eff. }\end{array}$ & Coeff. & $\begin{array}{l}\text { Marg. } \\
\text { eff. }\end{array}$ & Coeff. & $\begin{array}{l}\text { Marg. } \\
\text { eff. }\end{array}$ & Coeff. & $\begin{array}{l}\text { Marg. } \\
\text { eff. }\end{array}$ \\
\hline Income & $\begin{array}{l}0.048 * * \\
(2.75)\end{array}$ & 0.013 & $\begin{array}{l}-0.01 \\
(0.35)\end{array}$ & -0.002 & $\begin{array}{l}0.036\left(^{*}\right) \\
(1.77)\end{array}$ & 0.007 & $\begin{array}{l}-0.044 \\
(1.52)\end{array}$ & -0.011 \\
\hline Difference & $\begin{array}{l}0.058 \\
(1.47)\end{array}$ & 0.016 & $\begin{array}{l}0.120^{* *} \\
(4.76)\end{array}$ & 0.026 & $\begin{array}{l}0.107 * * \\
(3.34)\end{array}$ & 0.021 & $\begin{array}{l}-0.026 \\
(0.79)\end{array}$ & -0.006 \\
\hline diff2neg & $\begin{array}{l}0.013 \\
(0.20)\end{array}$ & 0.004 & $\begin{array}{l}0.032 \\
(1.00)\end{array}$ & 0.007 & $\begin{array}{l}0.009 \\
(0.20)\end{array}$ & 0.002 & $\begin{array}{l}-0.042 \\
(0.78)\end{array}$ & -0.010 \\
\hline diff2pos & $\begin{array}{l}-0.024 \\
(1.36)\end{array}$ & -0.006 & $\begin{array}{l}-0.023 * \\
(2.14)\end{array}$ & -0.005 & $\begin{array}{l}-0.01 \\
(0.58)\end{array}$ & -0.002 & $\begin{array}{l}0.006 \\
(0.36)\end{array}$ & 0.001 \\
\hline Observations & 23690 & & 23810 & & 23279 & & 23615 & \\
\hline $\begin{array}{l}\text { Wald-test } \\
\text { (income - difference) }\end{array}$ & 0.04 & & $10.16^{* *}$ & & $3.50(*)$ & & 0.13 & \\
\hline Prob $>$ chi 2 & 0.8392 & & 0.0014 & & 0.0613 & & 0.7136 & \\
\hline Pseudo R2 & 0.0056 & & 0.0058 & & 0.0056 & & 0.0097 & \\
\hline
\end{tabular}


Table 2 (cont.)

National Subsistence Income: Compliance with Social Norms

\begin{tabular}{lllllll}
\hline & $\begin{array}{l}\text { Tax morale } \\
\text { Coeff. }\end{array}$ & Marg. eff. & $\begin{array}{l}\text { Benefit morale } \\
\text { Coeff. }\end{array}$ & Marg. eff. & $\begin{array}{l}\text { Right of friend } \\
\text { Coeff. }\end{array}$ & Marg. eff. \\
\hline Income & -0.014 & -0.005 & $0.264^{*}$ & 0.105 & $0.239\left(^{*}\right)$ & 0.076 \\
& $(0.15)$ & & $(2.00)$ & & $(1.73)$ & \\
Difference & $0.119^{* *}$ & 0.044 & $0.273^{* *}$ & 0.108 & 0.112 & 0.036 \\
& $(2.93)$ & & $(5.17)$ & & $(1.61)$ & \\
diff2neg & $0.986^{*}$ & 0.360 & -0.196 & -0.078 & -1.282 & -0.409 \\
& $(2.17)$ & & $(0.35)$ & & $(1.64)$ & \\
diff2pos & -0.017 & -0.006 & $-0.058^{* *}$ & -0.023 & $-0.032\left(^{*}\right)$ & -0.010 \\
& $(1.37)$ & & $(3.41)$ & & $(1.80)$ & \\
\hline Observations & 23969 & & 24193 & & 22301 & \\
\hline Wald-test & & & & & & \\
(income-difference) & 1.33 & & 0.00 & & 0.54 & \\
Prob $>$ chi2 & 0.2479 & & 0.9551 & & 0.4641 & \\
Pseudo R2 & 0.0217 & & 0.0336 & & & \\
\hline
\end{tabular}

Table 2a (cont.)

National Average Income: Compliance with Social Norms

\begin{tabular}{lllllll}
\hline & $\begin{array}{l}\text { Tax morale } \\
\text { Coeff. }\end{array}$ & Marg. eff. & $\begin{array}{l}\text { Benefit morale } \\
\text { Coeff. }\end{array}$ & Marg. eff. & $\begin{array}{l}\text { Right of friend } \\
\text { Coeff. }\end{array}$ & Marg. eff. \\
\hline Income & 0.046 & 0.017 & $0.232^{* *}$ & 0.092 & $0.159^{* *}$ & 0.051 \\
& $(1.40)$ & & $(4.47)$ & & $(3.00)$ & \\
Difference & $0.121^{* *}$ & 0.044 & $0.116^{*}$ & 0.046 & -0.049 & -0.016 \\
& $(3.34)$ & & $(2.53)$ & & $(0.94)$ & \\
diff2neg & 0.067 & 0.024 & $-0.104\left(^{*}\right)$ & -0.041 & $-0.212^{*}$ & -0.068 \\
& $(1.33)$ & & $(1.92)$ & & $(2.53)$ & \\
diff2pos & -0.028 & -0.010 & $-0.034\left(^{*}\right)$ & -0.014 & 0.002 & 0.001 \\
& $(1.60)$ & & $(1.92)$ & & $(0.08)$ & \\
\hline Observations & 23969 & & 24193 & & 22301 & \\
\hline Wald-test & & & & & $8.57^{* *}$ & \\
(income - difference) & 2.22 & & 2.60 & & 0.0034 & \\
Prob > chi2 & 0.1364 & & 0.1068 & & 0.0540 & \\
Pseudo R2 & 0.0217 & & 0.0335 & & & \\
\hline
\end{tabular}


Table 2 (cont.)

National Subsistence Income: Voluntary Work

\begin{tabular}{|c|c|c|c|c|c|c|c|c|}
\hline & \multicolumn{2}{|l|}{ Politics } & \multicolumn{2}{|l|}{ Charity } & \multicolumn{2}{|l|}{ Religion } & \multicolumn{2}{|l|}{ Other } \\
\hline & Coeff. & Marg. eff. & Coeff. & Marg. eff. & Coeff. & Marg. eff. & Coeff. & Marg. eff. \\
\hline Income & $\begin{array}{l}0.044 \\
(0.35)\end{array}$ & 0.001 & $\begin{array}{l}0.681^{* *} \\
(3.53)\end{array}$ & 0.085 & $\begin{array}{l}0.629 * * \\
(4.20)\end{array}$ & 0.025 & $\begin{array}{l}0.435^{* *} \\
(3.90)\end{array}$ & 0.056 \\
\hline Difference & $\begin{array}{l}-0.134\left(^{*}\right) \\
(1.71)\end{array}$ & -0.004 & $\begin{array}{l}-0.195^{* *} \\
(2.80)\end{array}$ & -0.024 & $\begin{array}{l}-0.038 \\
(0.46)\end{array}$ & -0.002 & $\begin{array}{l}0.045 \\
(0.89)\end{array}$ & 0.006 \\
\hline diff2neg & $\begin{array}{l}-0.043 \\
(0.03)\end{array}$ & -0.001 & $\begin{array}{l}-2.143 \\
(1.49)\end{array}$ & -0.268 & $\begin{array}{l}-0.403 \\
(0.36)\end{array}$ & -0.016 & $\begin{array}{l}1.340 \\
(1.31)\end{array}$ & 0.173 \\
\hline $\operatorname{diff} 2 p o s$ & $\begin{array}{l}0.043(*) \\
(1.82)\end{array}$ & 0.001 & $\begin{array}{l}0.033 \\
(1.42)\end{array}$ & 0.004 & $\begin{array}{l}-0.022 \\
(0.87)\end{array}$ & -0.001 & $\begin{array}{l}-0.037^{*} \\
(2.37)\end{array}$ & -0.005 \\
\hline Observations & 24362 & & 24396 & & 24330 & & 24172 & \\
\hline $\begin{array}{l}\text { Wald-test } \\
\text { (income-difference) }\end{array}$ & 1.04 & & $15.99 * *$ & & $11.29 * *$ & & 7.97* & \\
\hline Prob $>$ chi 2 & 0.3068 & & 0.0001 & & 0.0008 & & 0.0048 & \\
\hline Pseudo R2 & 0.0608 & & 0.0569 & & 0.2151 & & 0.0800 & \\
\hline
\end{tabular}

Table 2a (cont.)

National Average Income: Voluntary Work

\begin{tabular}{|c|c|c|c|c|c|c|c|c|}
\hline & Politics & & Charity & & Religion & & Other & \\
\hline & Coeff. & Marg. eff. & Coeff. & Marg. eff. & Coeff. & Marg. eff. & Coeff. & Marg. eff. \\
\hline Income & $\begin{array}{l}-0.038 \\
(0.83)\end{array}$ & -0.001 & $\begin{array}{l}0.179^{*} \\
(2.31)\end{array}$ & 0.022 & $\begin{array}{l}0.222 * * \\
(3.99)\end{array}$ & 0.009 & $\begin{array}{l}0.176^{* *} \\
(4.20)\end{array}$ & 0.023 \\
\hline Difference & $\begin{array}{l}-0.071 \\
(0.84)\end{array}$ & -0.002 & $\begin{array}{l}-0.218^{* *} \\
(3.73)\end{array}$ & -0.027 & $\begin{array}{l}-0.202^{*} \\
(2.41)\end{array}$ & -0.008 & $\begin{array}{l}-0.129^{*} \\
(2.20)\end{array}$ & -0.017 \\
\hline diff2neg & $\begin{array}{l}0.032 \\
(0.27)\end{array}$ & 0.001 & $\begin{array}{l}-0.094 \\
(0.97)\end{array}$ & -0.012 & $\begin{array}{l}-0.184^{*} \\
(2.05)\end{array}$ & -0.007 & $\begin{array}{l}-0.116 \\
(1.53)\end{array}$ & -0.015 \\
\hline diff2pos & $\begin{array}{l}0.057 \\
(1.56)\end{array}$ & 0.002 & $\begin{array}{l}0.082 * * \\
(3.37) \\
\end{array}$ & 0.010 & $\begin{array}{l}0.04 \\
(1.13)\end{array}$ & 0.002 & $\begin{array}{l}0.017 \\
(0.84)\end{array}$ & 0.002 \\
\hline Observations & 24362 & & 24396 & & 24330 & & 24172 & \\
\hline $\begin{array}{l}\text { Wald-test } \\
\text { (income - difference) }\end{array}$ & 0.11 & & $15.48^{* *}$ & & $18.79^{* *}$ & & $19.97 * *$ & \\
\hline Prob $>$ chi2 2 & 0.7374 & & 0.0001 & & 0.0000 & & 0.0000 & \\
\hline Pseudo R2 & 0.0609 & & 0.0571 & & 0.2152 & & 0.0799 & \\
\hline
\end{tabular}




\section{Appendix}

Table A1

Description of Control Variables and Summary Statistics

\begin{tabular}{|c|c|c|c|c|c|c|}
\hline Variable & Obs. & Mean & Std. Dev. & Min & Max & $\begin{array}{c}\text { Based on the } \\
\text { VWS variables }\end{array}$ \\
\hline & & & & & & OECD \\
\hline Regional subsistence & 24166 & 03735 & 06486 & 00000 & 22344 & $\begin{array}{l}\text { equivalized } \\
\text { V216 }\end{array}$ \\
\hline Difference from regional & & & & & & \\
\hline subsistence income $/ 10000$ & 24166 & 0.0014 & 0.3799 & -1.9946 & 5.9116 & See above \\
\hline $\begin{array}{l}\text { Difference squared } \\
\text { if income }<0\end{array}$ & 24166 & 0.0537 & 0.2269 & 0.0000 & 3.9784 & See above \\
\hline $\begin{array}{l}\text { Difference squared } \\
\text { if income }>0\end{array}$ & 24166 & 0.0906 & 0.6104 & 0.0000 & 34.9467 & See above \\
\hline $\begin{array}{l}\text { National subsistence income/ } \\
10000\end{array}$ & 24166 & 0.3732 & 0.6443 & 0.0000336 & 24166 & See above \\
\hline $\begin{array}{l}\text { Difference from national } \\
\text { subsistence. income/10000 }\end{array}$ & 24166 & 0.0016 & 0.3865 & -1.7924 & 24166 & See above \\
\hline $\begin{array}{l}\text { Difference squared } \\
\text { if income }<0\end{array}$ & 24166 & 0.0546 & 0.2232 & 0.0000 & 24166 & See above \\
\hline $\begin{array}{l}\text { Difference squared } \\
\text { if income }>0\end{array}$ & 24166 & 0.0948 & 0.6333 & 0.0000 & 24166 & See above \\
\hline $\begin{array}{l}\text { Regional average income/ } \\
10000\end{array}$ & 24166 & 0.3735 & 0.6486 & 0.0000 & 2.2344 & See above \\
\hline $\begin{array}{l}\text { Difference from regional } \\
\text { income } / 10000\end{array}$ & 24166 & 0.0014 & 0.3799 & -1.9946 & 5.9116 & See above \\
\hline $\begin{array}{l}\text { Difference squared } \\
\text { if income }<0\end{array}$ & 24166 & 0.0537 & 0.2269 & 0.0000 & 3.9784 & See above \\
\hline $\begin{array}{l}\text { Difference squared } \\
\text { if income }>0\end{array}$ & 24166 & 0.0906 & 0.6104 & 0.0000 & 34.9467 & See above \\
\hline $\begin{array}{l}\text { National average income/ } \\
10000\end{array}$ & 24166 & 0.3732 & 0.6443 & 0.0000 & 1.9632 & See above \\
\hline $\begin{array}{l}\text { Difference from national } \\
\text { average income } / 10000\end{array}$ & 24166 & 0.0016 & 0.3865 & -1.7924 & 5.8669 & See above \\
\hline $\begin{array}{l}\text { Difference squared } \\
\text { if income }<0\end{array}$ & 24166 & 0.0546 & 0.2232 & 0.0000 & 3.2129 & See above \\
\hline $\begin{array}{l}\text { Difference squared } \\
\text { if income }>0\end{array}$ & 24166 & 0.0948 & 0.6333 & 0.0000 & 34.4201 & See above \\
\hline Female & 24166 & 0.5322 & 0.4990 & 0 & 1 & V200 \\
\hline Age $30-39$ & 24166 & 0.2204 & 0.4145 & 0 & 1 & V201 \\
\hline Age $40-49$ & 24166 & 0.1955 & 0.3966 & 0 & 1 & V201 \\
\hline Age $50-59$ & 24166 & 0.1594 & 0.3661 & 0 & 1 & V201 \\
\hline Age $60-69$ & 24166 & 0.1391 & 0.3460 & 0 & 1 & V201 \\
\hline Age $70-79$ & 24166 & 0.0812 & 0.2731 & 0 & 1 & V201 \\
\hline Age 80 & 24166 & 0.0147 & 0.1205 & 0 & 1 & V201 \\
\hline Level of education & 24166 & 4.5664 & 1.4641 & 1 & 7 & V205 \\
\hline Level of education squared & 24166 & 22.9955 & 13.5845 & 1 & 49 & V205 \\
\hline Single & 24166 & 0.1888 & 0.3913 & 0 & 1 & V202 \\
\hline Separated or divorced & 24166 & 0.0742 & 0.2620 & 0 & 1 & V202 \\
\hline Widowed & 24166 & 0.0874 & 0.2825 & 0 & 1 & V202 \\
\hline attendance of relig. services & 24166 & 2.3303 & 2.0161 & 1 & 9 & V59 \\
\hline
\end{tabular}


Table A1

Description of Variables and Summary Statistics (cont.)

\begin{tabular}{lcccrrr}
\hline \multicolumn{1}{c}{ Variable } & Obs. & Mean & Std. Dev. & Min & Max & $\begin{array}{c}\text { Based on the } \\
\text { VWS variables }\end{array}$ \\
\hline Catholic & 24166 & 0.4179 & 0.4932 & 0 & 1 & V217 \\
Jewish & 24166 & 0.0309 & 0.1730 & 0 & 1 & V217 \\
Protestant & 24166 & 0.2006 & 0.4005 & 0 & 1 & V217 \\
Orthodox & 24166 & 0.0583 & 0.2343 & 0 & 1 & V217 \\
No religion & 24166 & 0.2335 & 0.4230 & 0 & 1 & V217 \\
Buddhist & 24166 & 0.0158 & 0.1249 & 0 & 1 & V217 \\
Muslim & 24166 & 0.0109 & 0.1039 & 0 & 1 & V217 \\
& & & & & & Community type \\
Urban & 24166 & 0.4827 & 0.4997 & 0 & 1 & variables \\
Rural area & 24166 & 0.2821 & 0.4500 & 0 & 1 & See above \\
Self-employed & 24166 & 0.0927 & 0.2899 & 0 & 1 & V206 \\
Unemployed & 24166 & 0.0545 & 0.2269 & 0 & 1 & V206 \\
Retired & 24166 & 0.1950 & 0.3962 & 0 & 1 & V206 \\
Housewife & 24166 & 0.1025 & 0.3033 & 0 & 1 & V206 \\
Disabled & 24166 & 0.0211 & 0.1437 & 0 & 1 & V206 \\
Out of labour force & 24166 & 0.0107 & 0.1028 & 0 & 1 & V206 \\
Germanic language & 24166 & 0.1849 & 0.3882 & 0 & 1 & V3 \\
Romance language & 24166 & 0.2199 & 0.4142 & 0 & 1 & V3 \\
Northern Germanic language & 24166 & 0.1213 & 0.3265 & 0 & 1 & V3 \\
Balto-Slavic countries & 24166 & 0.2957 & 0.4563 & 0 & 1 & V3 \\
Other non-English language & 24166 & 0.1208 & 0.3259 & 0 & 1 & V3 \\
\hline This table is based on the number of observations in the happiness regressions. &
\end{tabular}

Table A2

Description of Dependent Variables and Summary Statistics

\begin{tabular}{lllrrrr}
\hline \multicolumn{1}{c}{ Variable } & Obs & Mean & Std. Dev. & Min & Max & $\begin{array}{c}\text { Based on the VWS } \\
\text { variables }\end{array}$ \\
\hline Happiness & 24166 & 2.8995 & 0.7370 & 1 & 4 & V4 \\
Advantage & 22509 & 2.6645 & 0.8606 & 1 & 4 & V18 \\
Generalized trust & 24290 & 2.2681 & 0.8022 & 1 & 4 & V19 \\
Confidence in parliament & 23690 & 2.4466 & 1.4098 & 1 & 5 & V20 \\
Confidence in courts & 23810 & 2.5375 & 1.2656 & 1 & 5 & V21 \\
Confidence in business & 23279 & 2.3072 & 1.2222 & 1 & 5 & V22 \\
Confidence in church & 23615 & 2.7124 & 1.3285 & 1 & 5 & V23 \\
Tax morale & 23969 & 2.9641 & 0.9445 & 1 & 4 & V16 \\
Benefit morale & 24193 & 3.3926 & 0.7923 & 1 & 4 & V17 \\
Right of friends & 22301 & 2.6728 & 0.5922 & 1 & 3 & V6 \\
Voluntary work - politics & 24362 & 1.1082 & 0.4624 & 1 & 4 & V32 \\
Voluntary work - charity & 24396 & 1.4560 & 0.9049 & 1 & 4 & V33 \\
Voluntary work - religion & 24330 & 1.2749 & 0.7499 & 1 & 4 & V34 \\
Other voluntary work & 24172 & 1.4566 & 0.9369 & 1 & 4 & V35 \\
\hline
\end{tabular}


Table A3

Descriptive Statistics for the 25 Countries Included

\begin{tabular}{lrrrrrrr}
\hline \multicolumn{1}{c}{ Country } & Freq. & Percent & Germanic & Romance & $\begin{array}{c}\text { Northern } \\
\text { Germanic }\end{array}$ & $\begin{array}{c}\text { Balto- } \\
\text { Slavic }\end{array}$ & Other \\
\hline Germany & 1,460 & 6.04 & 1 & 0 & 0 & 0 & 0 \\
Austria & 656 & 2.71 & 1 & 0 & 0 & 0 & 0 \\
Hungary & 817 & 3.38 & 0 & 0 & 0 & 1 & 0 \\
Italy & 601 & 2.49 & 0 & 1 & 0 & 0 & 0 \\
Netherlands & 1,425 & 5.9 & 1 & 0 & 0 & 0 & 0 \\
Norway & 1,237 & 5.12 & 0 & 0 & 1 & 0 & 0 \\
Sweden & 848 & 3.51 & 0 & 0 & 1 & 0 & 0 \\
Czech Republic & 690 & 2.86 & 0 & 0 & 0 & 1 & 0 \\
Slovenia & 675 & 2.79 & 0 & 0 & 0 & 1 & 0 \\
Poland & 963 & 3.98 & 0 & 0 & 0 & 1 & 0 \\
Bulgaria & 937 & 3.88 & 0 & 0 & 0 & 1 & 0 \\
Russia & 963 & 3.98 & 0 & 0 & 0 & 1 & 0 \\
New Zealand & 777 & 3.22 & 0 & 0 & 0 & 0 & 0 \\
Canada & 610 & 2.52 & 0 & 0 & 0 & 0 & 0 \\
Philippines & 1,063 & 4.4 & 0 & 0 & 0 & 0 & 1 \\
Israel & 829 & 3.43 & 0 & 0 & 0 & 0 & 1 \\
Japan & 1,028 & 4.25 & 0 & 0 & 0 & 0 & 1 \\
Spain & 1,552 & 6.42 & 0 & 1 & 0 & 0 & 0 \\
Latvia & 980 & 4.06 & 0 & 0 & 0 & 1 & 0 \\
Slovak Republic & 1,120 & 4.63 & 0 & 0 & 0 & 1 & 0 \\
France & 855 & 3.54 & 0 & 1 & 0 & 0 & 0 \\
Portugal & 1,069 & 4.42 & 0 & 1 & 0 & 0 & 0 \\
Chile & 1,237 & 5.12 & 0 & 1 & 0 & 0 & 0 \\
Denmark & 846 & 3.5 & 0 & 0 & 1 & 0 & 0 \\
Switzerland & 928 & 3.84 & 1 & 0 & 0 & 0 & 0 \\
& & & & & & & \\
Total & 24,166 & 100 & & & 0 & & 0 \\
\hline Nat & & 0 & 0 & 0 & & \\
\end{tabular}

Number of countries and observations based on the happiness regression model. 


\section{References}

Ainslie, G. (1992), Picoeconomics: The Strategic Interaction of Successive Motivational States within the Person, Cambridge: Cambridge University Press.

Akerlof, G. A. and Yellen, J. L. (1990), 'The fair wage-effort hypothesis and unemployment, Quarterly Journal of Economics, vol. 105, pp. 255-284.

Anderson, G. M. and Tollison, R. D. (1992), 'Morality and monopoly: the constitutional political economy of religious rules', CATO Journal, vol. 13, pp. 373-391.

Alm, J., McClelland, G. H. and Schulze, W. D. (1992), 'Why do people pay taxes?', Journal of Public Economics, vol. 48, pp. 21-48.

Alm, J., McClelland, G. H. and Schulze, W. D. (1999), 'Changing the social norm of tax compliance by voting', KYKLOS, vol. 48, pp. 141-171.

Alpizar, F., Carlsson, F. and Johansson-Stenman, O. (2005), 'How much do we care about absolute versus relative income and consumption?', Journal of Economic Behavior and Organization, vol. 56, pp. 405-421.

Archibald, G. C. and Donaldson, D. (1979), 'Notes on economic equality', Journal of Public Economics, vol. 12, pp. 205-214.

Aristotle (1924), Rhetoric, Book II, in (W. D. Ross, ed.), Works of Aristotle, Vol. XI, Oxford: Clarendon Press.

Bacon, F. (1625/1890), The Essays of Counsels, Civil and Moral, Oxford: Clarendon Press.

Baker, W. (2005), America's Crisis of Values, Princeton: Princeton University Press.

Becker, G. S. (1974), ‘A theory of social interaction', Journal of Political Economy, vol. 82, pp. 1063-1093.

Boskin M. and Sheshinski, E. (1978), 'Optimal redistribution taxation when individual welfare depends upon relative income', Quarterly Journal of Economics, vol. 92, pp. 589-601.

Bjørnskov, C. (2005), 'The multiple facets of social capital', forthcoming in European Journal of Political Economy.

Brennan, G. (1973), 'Pareto desirable redistribution: the case of malice and envy', Journal of Public Economics, vol. 2, pp. 173-183.

Clark, A. and Oswald A. (1996), 'Satisfaction and comparison income', Journal of Public Economics, vol. 61, pp. 359-81.

Dorn, D., Fischer, J. A. V., Kirchgässner, G. and Sousa-Poza, A. (2005), Is It Culture or Democracy? The Impact of Democracy, Income, and Culture on Happiness, University of St. Gallen, Department of Economics Working Paper Series 2005-12, St. Gallen, Switzerland.

Duesenberry, J. S. (1949), Income, Saving and the Theory of Consumer Behavior, Harvard: University of Harvard Press. 
Easterlin, R. (1974), 'Does economic growth improve the human lot? Some empirical evidence', in (P. A. David and M. W. Reder, eds.), Nations and Households in Economic Growth: Essays in Honor of Moses Abramovitz, New York: Academic Press, pp. 89-125.

Easterlin, R. (1995), 'Will raising the incomes of all increase the happiness of all?', Journal of Economic Behavior and Organization, vol. 27, pp. 35-47.

Easterlin, R. A. (2001), 'Income and happiness: towards a unified theory', Economic Journal, vol. 111, pp. 465-84.

Elster, J. (1991), 'Envy in social life', in (R. J. Zeckhauser, ed.), Strategy and Choice, Cambridge, Mass.: MIT Press, pp. 49-82.

Ferrer-i-Carbonell, A. (2005), 'Income and well-being: an empirical analysis of the comparison income effect', Journal of Public Economics, vol. 89, pp. 997-1019.

Festinger, L. (1954), 'A theory of social comparison processes', Human Relations, vol. 7, pp. 117-140.

Foley, D. (1967), 'Resource allocation and the public sector', Yale Economic Essays, vol. 7, pp. 45-98.

Foster, G. M. (1967), Tzintzuntzan: Mexican Peasants in a Changing World, Boston: Little, Brown and Company.

Frank, R. (1985), Choosing the Right Pond: Human Behaviour and the Quest for Status, Oxford: Oxford University Press.

Frank, R. H. (1991), 'Positional externalities', in (R. J. Zeckhauser, ed.), Strategy and Choice. Cambridge, Mass.: MIT Press, pp. 25-47.

Frank, R. H. and Sunstein, C. R. (2001), 'Cost-benefit analysis and relative position', University of Chicago Law Review, vol. 68, pp. 323-374.

Frey, B. S. (1997), Not Just for the Money. An Economic Theory of Personal Motivation, Cheltenham, UK: Edward Elgar Publishing.

Frey, B. S. (2003), The Role of Deterrence and Tax Morale in Taxation in the European Union, Jelle Zijlstra Lecture, Netherlands Institute for Advanced Study in the Humanities and Social Sciences (NIAS).

Frey, B. S. and Feld, L. P. (2002), Deterrence and Morale in Taxation: An Empirical Analysis, CESifo Working Paper No. 760, August 2002.

Frey, B. S. and Torgler, B. (2004), Taxation and Conditional Cooperation, CREMA Working Paper 2004-20, Center for Research in Economics, Management and the Arts, Basel, Switzerland.

Friedman, M. (1962), Capitalism and Freedom, Chicago: University of Chicago Press.

Glaeser, E., Laibson, D., Scheinkman, J. A. and Soutter, C. L. (2000), 'Measuring trust', Quarterly Journal of Economics, vol. 115, pp. 811-846.

Groot, W. and van den Brink, H. M. (1999), 'Overpayment and earnings satisfaction: an application of an ordered response tobit model', Applied Economics Letters, vol. 6, pp. 235-238. 
Halla, M. and Schneider, F. (2005), Taxes and Benefits: Two Distinct Options to Cheat on the State?, Economics Working Papers 2005-05, Department of Economics, Johannes Kepler University, Linz, Austria.

Heston, A., Summers, R. and Aten, B. (2002), Penn World Table Version 6.1, Center for International Comparisons at the University of Pennsylvania (CICUP), October 2002.

Holländer, H. (2001), 'On the validity of utility statements: standard theory versus duesenberry's', Journal of Economic Behavior and Organization, vol. 45, pp. 227-249.

Hull, B. B. and Bold, F. (1994), 'Hell, religion, and cultural change', Journal of Institutional and Theoretical Economics, vol. 150, pp. 447-464.

Kant, I. (1785/1964), The Metaphysic of Morals, New York: Harper and Row.

Keynes, J. M. (1930), 'Economic possibilities for our grandchildren', in (J. M. Keynes), Essays in Persuasion, New York: Norton.

Kingdon, G. and Knight, J. (2004). Community, Comparisons and Subjective Well-Being in a Divided Society, June 2004 CSAE WPS/2004-21, Oxford, UK.

Kirchsteiger, G. (1994), 'The role of envy in ultimatum games', Journal of Economic Behavior and Organization, vol. 25, pp. 373-389.

Knack, S. (2000), Social Capital and the Quality of Government: Evidence from the U.S. States, World Bank Policy Research Working Paper Series, 2504.

Knack, S. and Keefer, P. (1997), 'Does social capital have an economic payoff? A cross-country investigation', Quarterly Journal of Economics, vol. 4, pp. 1251-1288.

Johansson-Stenman, O., Carlsson, F. and Daruvala, D. (2005), 'Measuring future grandparents' preferences for equality and relative standing', Economic Journal, vol. 112, pp. 362-383.

Layard, R. (2003), Income and Happiness: Rethinking Economic Policy, Lecture 2, London School of Economics, UK (see cep.lse.ac.uk/events/lectures/layard/RL040303.pdf).

Leibenstein, H. (1950), 'Bandwagon, snob and Veblen effects in the theory of consumers' demand', Quarterly Journal of Economics, vol. 65, pp. 183-207.

Lewis, A. (1982), The Psychology of Taxation, Oxford: Martin Robertson.

Luttmer, E. F. P. (2005), 'Neighbors as negatives: relative earnings and well-being', Quarterly Journal of Economics, vol. 120, pp. 963-1002.

Lyubomirsky, S. (2001), 'Why are some people happier than others? The role of cognitive and motivational processes in well-being. American Psychologist. 56: 239-249.

Marshall, A. (1961), Principles of Economics, London: Macmillan.

Marx, K. (1849), 'Wage labour and capital', in (K. Marx and F. Engel), Selected Works. Vol.1, Moscow: Progress Publishers.

McAdams, R. H. (1992), 'Relative preferences', Yale Law Journal, vol. 102, pp. 1-104.

McBride, M. (2001), 'Relative-income effects on subjective well-being in the cross-section', Journal of Economic Behavior and Organization, vol. 45, pp. 251-278. 
Moulton, B. (1990), An Illustration of a Pitfall in Estimating the Effects of Aggregate Variables on Micro Units, The Review of Economics and Statistics, May, pp. 334-338

Mui, V.-L. (1995), 'The economics of envy', Journal of Economic Behavior and Organization, vol. 26, pp. 311-336.

Neumark, D. and Postlewaite, A. (1998), 'Relative income concerns and the rise in married women's employment', Journal of Public Economics, vol. 70, pp. 157-183.

Paldam, M. (2000), 'Social capital: one or many? Definition and measurement', Journal of Economic Surveys, vol. 14, pp. 629-653.

Pigou, A. C. (1920), The Economics of Welfare, London: MacMillan.

Pollak, R. A. (1976), 'Interdependent preferences', American Economic Review, vol. 66, pp. 309-320.

Pommerehne, W. W., Hart, A. and Frey, B. S. (1994), 'Tax morale, tax evasion and the choice of policy instruments in different political systems', Public Finance, vol. 49 (Supplement), pp. 52-69.

Putnam, R. (2000), Bowling Alone: Collapse and Revival of American Community, New York, Simon and Schuster.

Putnam, R. (2001), 'Social capital: measurement and consequences', Isuma, vol. 2, pp. 41-51.

Roth, J. A., Scholz, J. T. and Witte, A. D. (eds.) (1989), Taxpayer Compliance, Vol. 1 and Vol. 2, Philadelphia: University of Pennsylvania Press.

Schaltegger, C. A. and Torgler, B. (2005), Trust and Fiscal Performance: A Panel Analysis with Swiss Data, Fondazione Eni Enrico Mattei (FEEM) Working Paper, No. 2005.61, Milan, Italy.

Schelling, T. C. (1978), Micromotives and Macrobehavior, New York: W. W. Norton.

Schoeck, H. (1966), Envy. A Theory of Social Behavior, Indianapolis: Liberty Fund.

Scitovsky, T. (1976), The Joyless Economy: An Inquiry Into Human Satisfaction and Consumer Dissatisfaction, Oxford: Oxford University Press.

Senik, C. (2004), Revitalizing Relativizing Income, Delta Working Paper 2004-17, Paris, France.

Slemrod, J. (1998), 'On voluntary compliance, voluntary taxes, and social capital', National Tax Journal, vol. 51, pp. 485-492.

Smith, A. (1759/1976), Theory of Moral Sentiments, Oxford: Clarendon Press.

Solnick, S. J. and Hemenway D. (1998), 'Is more always better? A survey on positional concerns', Journal of Economic Behavior and Organization, vol. 37, pp. 373-383.

Stouffer, S. A. (1949), The American Soldier, Princeton: Princeton University Press.

Stutzer, A. (2004), 'The role of income aspirations in individual happiness', Journal of Economic Behavior and Organization, vol. 54, pp. 89-109.

Torgler, B. (2002), 'Speaking to theorists and searching for facts: tax morale and tax compliance in experiments', Journal of Economic Surveys, vol. 16, pp. 657-684.

Torgler, B. (2003), 'To evade taxes or not: that is the question', Journal of Socio-Economics, vol. 32, pp. 283-302. 
Torgler, B. (2005a), 'Tax morale in Latin America', Public Choice, vol. 122, pp. 133-157.

Torgler, B. (2005b), 'Tax morale and direct democracy', European Journal of Political Economy, vol. 21, pp. 525-531.

Torgler, B. (2005c), 'A knight without a sword? The effects of audit courts on tax morale', Journal of Institutional and Theoretical Economics, vol. 161, pp. 735-760.

Torgler, B. (2006a), 'The importance of faith: tax morale and religiosity', forthcoming in Journal of Economic Behavior and Organization.

Torgler, B. (2006b), Tax Compliance and Tax Morale: A Theoretical and Empirical Analysis, forthcoming: Edward Elgar.

Torgler, B., Schmidt, S. and Frey, B. S. (2005), Relative Income Position and Performance: An Empirical Panel Analysis, unpublished manuscript.

Tsou, M. W. and Liu, J. T. (2001), 'Happiness and domain satisfaction in Taiwan', Journal of Happiness Studies, vol. 2, pp. 269-288.

Tversky, A. and Griffin, D. (1991), 'Endowment and contrast in judgments of well-being, in (R. J. Zeckhauser, ed.), Strategy and Choice, Cambridge, Mass.: MIT Press, pp. 297-318.

Uslaner, E. M. (2002), The Moral Foundation of Trust, Cambridge: Cambridge University Press.

Varian, H. R. (1974), 'Equity, envy, and efficiency', Journal of Economic Theory, vol. 9, pp. 63-91.

Van Doorslaer, E. and Masseria, C. (2004), Income-Related Inequalities in the Use of Medical Care in 21 OECD Countries, OECD Health Working Papers, No. 14/2004.

Veblen, T. (1899), The Theory of the Leisure Class, New York: MacMillan.

Watson, R., Storey, D., Wynarczyk, P., Keasey, K. and Short, H. (1996), 'The relationship between job satisfaction and managerial remuneration in small and medium-sized enterprises: an empirical test of "Comparison Income" and "Equity Theory" Hypotheses', Applied Economics, vol. 28, pp. 567-76.

Zeckhauser, R. J. (ed.) (1991), Strategy and Choice, Cambridge: MIT Press. 